\title{
Yerel Siyasette “Kadın Temsili Sorunsalının” 31 Mart 2019 Mahalli İdareler Seçimi Sonuçları Özelinde Analizi: Trabzon İli Örneği
}

\author{
At Local Politics "Woman Representation Problem's" Analysis of Specific to the Results of the Local \\ Administrators Election on 31 March 2019: The Case of Trabzon
}

\author{
Zeynep ŞAHIN \\ Doktorant, Karadeniz Teknik Üniversitesi, \\ SBE, Kamu Yönetimi A.B.D., \\ zeyneperbassahin@gmail.com \\ https://orcid.org/0000-0001-6013-5888
}

Makale Başvuru Tarihi: 16.11.2020

Makale Kabul Tarihi: 22.01.2020

Makale Türü: Araştırma Makalesi

\section{ÖZET}

$\begin{aligned} & \text { Anahtar } \\ & \text { Kelimeler: }\end{aligned}$
Siyasal Temsil,
Kadın,
Yerel Siyaset,
31 Mart 2019
Seçimleri,
Trabzon,

Keywords:

Political

Representation,

Woman,

Local Politics,

31 March 2019

Election,

Trabzon
Insan haklarının vazgeçilmez değerler şeklinde kabul edildiği ülkelere bakıldiğında, kadınların siyasal, ekonomik, kültürel ve sosyal alana katılımını mümkün kılacak tüm haklardan yararlanma konusunda erkeklerle eşit olması gerektiği anlayışı hâkimdir. Bu anlayış, insan hakları belgeleri, uluslararası sözleşme hatta ülkelerin mevzuatında olmasına rağmen, gelişmişlik düzeyleri ne düzeyde olursa olsun pek çoğunda hâlen, yaşamın temel alanlarını teşkil eden çalışma hayatı, sağlık, eğitim ve siyasal yaşamda temsil hususunda toplumsal cinsiyet bağlamında eşitliğin yakalanamadı̆̆ görülmektedir. Bu problem siyasal alanda, özellikle yerel siyasette temsil bağlamında kendini çok daha fazla hissettirmektedir. Bu doğrultuda çalıșmanın amacı, ülkemizde "kadının yerel siyasette temsilinin yetersizliği" sorunsalının 31 Mart 2019 Mahalli İdareler Seçimleri ölçeğinde Trabzon İli özelindeki durumunun incelenmesidir. Betimsel analiz yönteminin kullanıldığ çalışmada, Trabzon İline ait 31 Mart 2019 Mahalli İdareler Seçimleri aday listeleri/sonuçları, Yüksek Seçim Kurulu (YSK)'nun ilân ettiği verilerden yararlanılmak suretiyle sunulmaktadır. Büyükşehir belediye başkanlığı başta olmak üzere, il sinırlarındaki merkez ile diğer belde belediye başkanı, belediye meclis, il genel meclisi üyeliğine "aday olma" ve "seçilme" ölçütleri bağlaminda kadın temsil oranları incelenmektedir. Çalışmanin sonucunda büyükşehir ve belde belediye başkanlı̆̆ına "aday olma" düzeyinde kadın temsili strasıyla \%22.2 ile \%1 oranında gerçekleştiği; fakat "seçilme", bağlamında temsile rastlanmadı̆̆ görülmektedir. Illçe belediye meclis ve il genel meclisi üyeliğine "aday olma" \%11.72, \% 7.05; "seçilme" düzeyinde kadın temsilinin \% 7,05, \%4.35'lik seviyede olduğu tespit edilmektedir. Türkiye'de kadınların yerel siyasette temsil konusunda "görünmezliği/yokluk durumu” yaşadı̆̆ ve ona "sembolik değer" yüklendiği savl, Trabzon İli örneğindeki verilerle doğrulanmaktadır. "Biçimsel ve niteliksel” olarak kadın temsilini değiştirecek mekanizmaların varlı̆̆ıyla söz konusu sorunsalın aşılacağı önerilmektedir.

\section{ABSTRACT}

Considering the countries where human rights are regarded as indispensable values, the understanding that women should be equal with men in enjoying all rights that will enable their participation in the political, economic,cultural and social sphere is prevalent. Although this understanding is included in human rights documents/international convention and even in the legislation of countries, regardless of their level of it is seen that quality in the context of gender still hasn't been achieved in term of working life, education representation in political life. This problem makes itself felt much more in the political sphere, especially in the context of representation in local politics. In this regard, the purpose of is study to examine the situation of "insufficient local representation of women" in the example of Trabzon in our country within the scope of the March 31, 2019 Local Administrations Elections. The descriptive analysis method used for the results of the 31 March 2019 Local Administrations Elections/results of the province of Trabzon were presented by means of the data announced by the Supreme Election Board. Female participation and representation rates were examined in the context of 'candidate' and 'election' criteria for membership, particularly for metropolitan municipality, central and district mayors, municipal councils and provincial councils. As a result of the study, women's representation at the 'candidate' level at the metropolitan and district mayoral level was $22.2 \%$ to $1 \%$; but there was no representation in the context of 'elected'. It was found that women's representation at the 'candidate' level was $11.72 \%, 7.05 \%$; women's representation at the 'elected' level was $7.05 \%, 4.35 \%$. The argument that women experience "invisibility/status of absence" and they are simply attributed a "symbolic value" has been confirmed by the data from the example of Trabzon province. It has been suggested that the problem in question will be overcome with the existence of mechanisms to change the representation of women as "formal and qualitative". 


\section{GIRISS}

Günümüzde demokrasi hâkim siyasal rejim kabul edildiğinden, savunduğu temel ilkelerden olan eşit katılım ve temsil uygulaması ülkelerin gelişmişlik düzeyini göstermesi bakımından elzemdir. Bu bağlamda kadınların siyasal temsilinin arttırılması hem yerel siyasetin demokratikleşmesinde ayrıca toplumsal cinsiyet eşitliğinin sağlanmasında önemlidir.

Türkiye'de kadınlar dünyanın pek çok ülkesindeki hem cinslerine göre siyasal haklara daha erken zamanda kavuşmuş olsa bile, günümüzde temsil oranları incelendiğinde çok fazla yolun alındığını söylemek güçtür. 1930 yılında belediye seçimlerine katılma, temsil hakk1 akabinde 1933'te muhtar olma ve ihtiyar heyetinde yer alma, 1934 'te seçme ve seçilme şeklindeki siyasal hakların kazanılma süreci, zaman içinde anayasa, yerel yönetim mevzuat, siyasi partiler yasalarındaki değişiklikler, toplumsal cinsiyet eşitliğini sağlamak amacıyla oluşturulan kurumlar ve geliştirilen politikalarla desteklenmektedir. Fakat kadının siyasal temsilindeki yetersizlik derinden hissedilmeye devam etmektedir.

Ülkemizdeki ataerkil toplum yapısının kadına, erkeğe yüklediği toplumsal roller nedeniyle siyasetin erkeksi bir alan olarak görülmesi, bu durumun başlıca faktörüdür. Özel alana hapsedilen ev işleri, çocuk eğitimine endekslenen kadın, kamusal alanda erkeklerle rekabet edecek olanağa sahip olamamaktadır. Kamusal alanın eril yapıyla kuşatılması sonucunda, kadın bu alandan ya tamamen dışlanma ya da çok az yer bulma şeklinde cereyan eden "görünmezlik ve yokluk" sorunsalıyla karşı karşıya kalmaktadır. Söz konusu anlayış, kadın temsilinin mevzuatta kalmasına, uygulama açısından sembolik rakamların ötesine geçememesine sebebiyet vermektedir. Siyasal alanda yaşanan bu sorun partilerce kadın temsiline çok az ya da aday sıralamasında sonlarda, kontenjan adaylığında mümkün mertebe hiç yer verilmeyerek desteklenmektedir. Ataerkil toplum yapısı kadının siyasal sistemle bağ kuramamasının başlıca faktörü olmakla birlikte gelir, meslek, eğitim, yaş, cinsiyet, yerleşim yeri vb. sosyo-ekonomik ve psikolojik faktörlerinde etkili olduğu göz ardı edilmemelidir.

Bu bağlamda çalışmada ilk olarak siyasal temsil, toplumsal cinsiyet kavramı bileşenleriyle açıklanarak kavramsal çerçeve oluşturulmaktadır. Söz konusu alanda karşılaşılan sorunlara değinilerek, katılımı artırmaya yönelik araçların yeterli(siz)liği tartışmaya açılmaktadır. Ardından kadınların siyasal temsil süreci tarihsel olarak kronolojik şekilde detaylı irdelenmektedir. En son kısımda betimsel analiz yöntemi kullanılmak suretiyle, kadınların yerel siyasetteki 'görünmezliği ve yokluk" ironisi ve "sembolik değer"' olarak görüldüğü savının tespiti amaciyla 31 Mart 2019 Mahalli İdareler Seçimlerinin Trabzon İli özelinde incelenmesine odaklanılmaktadır.

\section{KAVRAMSAL ÇERÇEVE}

\subsection{Seçime Dayalı Siyasetin Temel Kavramlarından Biri Olarak Siyasal Temsil}

Siyasal katılım ve temsil, ulusal, yerel düzeyde gerçekleşen seçimlerin dayanağını oluşturduğundan siyasetin temel kavramları olarak kabul görmektedir (Kurtoğlu, 2004:322). Siyasal katılımın, bireysel ve toplumsal olarak iki boyutu vardır. Siyasal temsil, toplumun sahip olduğu egemenlik hakkının onun adına, seçeceği kimseler tarafından kullanılmasını içeren boyutunu ifade eder. Bu noktada öncelikle siyasal katılım kavramından bahsedilmesi önem arz etmektedir.

Siyasal katılım kavramı, farklı yaklaşımların ilgi alanına girdiğinden üzerinde konsensüs (oydaşma) sağlanmış bir tanımından bahsetmek zordur. Söz konusu kavramı Çukurçayır (2012:39), yalnızca seçimlere katılma şeklinde dar; siyasal karar alma süreçlerinin bütün aşamalarında yer almayı içine alacak biçimde geniş anlamda ele almaktadır. Çam (1987:279) bu tasnifi destekler şekilde, kimi bireylerin siyasete ilgisiz bir şekilde yalnızca oy verirken ve yahut hiç vermezken; bazıların ise siyaseti yakından takip etme, partiye üye olma, etkin görev üstlenme gibi etkin faaliyet göstererek katılımı gerçekleştirdiğinin altını çizmektedir. Kışlalı (1987:335) siyasal katılımı, "yurttaşların devletin değişik kademelerinde alınan karar, uygulamaları etkileme girişimleri”, şeklinde ifade etmektedir. Kalaycıŏlu (1983:10), "kişinin özerk olarak yapmış olduğu tercihler ve vermiş olduğu kararlar neticesinde siyasal karar alma mevkiine gelecekleri veya hali hazırda var olanlart etkilemek amactyla giriştikleri eylem/etkinlik olarak" tanımlamaktadır. Huntington ve Nelson (1976:4), "hükümetin karar alma süreçlerinin önceden sivil vatandaşlar tarafindan tasarlanmış etkinlikler" olarak nitelemektedir. Bir başka tanıma göre siyasal bir davranış çeşidi olarak vatandaşların, alınan/alınacak siyasal, toplumsal, ekonomik kararlar akabinde gösterdikleri refleks, eğilim ve tutumlardan meydana gelmektedir (Öztekin, 2007:229). Bu farklı tanımlamalardaki ortak noktanın, "yurttaşların siyasal karar alma aşamalarında var olduğunu gösterme 
gayreti" olduğu açıkça ortadır. Bazıları sadece oy verme ve seçimlere vurgu yaparken, kimileri bunların yanı sıra vatandaşların tutum/davranış, faaliyet ve eğilimlerini de içeren bir yöntem izlediği görülmektedir.

Siyasal katılım farklı biçim, düzey ve boyutlarda gerçekleşme durumuna göre kategorilere ayrılmaktadır (Dinç, 2002:12-13). Başka bir ifadeyle katılım; bireylerin siyasal gelişmelere duyduğu ilgi, siyasal katılım faaliyetlerine iştirak düzeylerini etkileyen belli başlı faktörlerden (sosyo-ekonomik, gelir, meslek, eğitim, yaş, cinsiyet vb.) dolayı eylem tür, yoğunluk düzeyi bakımından farklı sınıflandırmalara tabi tutulmaktadır. Dahl'ın (1963:57) siyasal katılımı sınıflandırmas1; "ilgi, önemseme ve bilgi, eylem" şeklindedir. Ona göre ilgi ve önemseme, siyasal olaylar karşısında merak ve önemi; bilgi ile eylem, olaylar hakkında sahip olunan bilgiyi, siyasal karar/uygulamaları etkileme bağlamında çaba sarf etme, siyasal olaylar içinde aktif görev alma şeklinde gerçekleşmektedir. Söz konusu dört boyut birbiriyle bağlantılı tutumlardan oluşmaktadır. Toplumu siyasal katılım açısından sınıflandırırken öncelikle siyasal tabaka ve bunun tam tersi şeklinde olan siyasal olmayan tabakadan bahsetmektedir. Akabinde iktidar peşinde koşanlar, son olarak iktidar sahiplerine vurgu yaparak, katılım açısından toplumsal bir yapı sunmaktadır. Milbrath ve Goel (1977:18) kolaylık, zorluk sınıflandırması bağlamında bir sıralama yapmaktadır; izleyici (gözlemleyici), geçiş (aracl) ve gladyatör (siyasal mücadeleye yönelik) eylemler. Siyasal katılma biçimlerini altılı bir kategoriye ayırmaktadır; aktif/pasif, sürekli/süreksiz, açı/gizli, zorunlu/bağımsız, sözlü/sözsüz, toplumsal olan/olmayan katılma. Huntington ve Nelson (1976:7) şekil, düzey bakımından katılımı şu şekilde sınıflandırır; lobicilik, iletişim kurma, şiddet, seçim etkinlikleri.

Bütün bu aktarımlardan anlaşılacağı gibi siyasal katılım çok sayıda değişkeni içine alan heterojen bir yapı arz etmektedir. Söz konusu yapı nedeniyle siyasal katılımı etkileyen faktörlerin kavranabilmesi amacıyla birey ve onun tutum, davranış vb. küçük ölçekte ifade edilebilecek değişkenlerden; örgütsel yapı, ülke, siyasal sistem/kültür vb. daha büyük ölçektekilere kadar pek çok faktörün ele alınması gerekmektedir. Bu bağlamda siyasal katılmayı etkileyen faktörleri sosyo-ekonomik ve psikolojik olmak üzere ikiye ayırmak mümkündür.

Sosyo-ekonomik faktörlere bakıldığında; gelir ve meslekten eğitim, yerleşim yerine, yaş ve cinsiyete kadar pek çok bileşeni barındırdığı görülmektedir. Siyasal katılmayı etkileyen psikolojik faktörler de mevcuttur. Bunlar sosyo-ekonomik etkenlerin birey üzerinde aynı düzeyde etkili olmaması sonucunda belirmektedir. Bireyin deneyimli, etkin oluşu, girişkenliği siyasal katılıma pozitif etki oluştururken; utangaçlık, yabancılaşma vb. durumlar negatif şekilde (Tosun ve Tepeciklioğlu, 2014:500) tesir etmektedir.

Siyasal katılımın bireysel ve toplumsal olmak üzere iki boyutu söz konusudur. Bireysel boyutunda cinsiyet bağlamında farklılıklar görülmezken, toplumsal kısmında kadın katılımının düşük olduğu göze çarpmaktadır. Toplumsal cinsiyet rolleri siyasal katılımı büyük ölçüde etkilemektedir. Cinsiyetçi bakış açısının kadına, erkeğe biçmiş olduğu işbölümü, özel ve kamusal alanın sınırlarını çizmektedir. Kadının yaptığı işler özel alanda gerçekleştiğinden apolitik olarak görülürken; toplumsal alanda faaliyet gösteren erkeğin çalışma alanı kamusal olarak kabul görmektedir (Sancar Üşür, 2000:204). Özetle, erkek toplumsal yapı bağlamında daha çok ev dış1 rollere sahip olduğundan yüksek; kadın ise ev içi rolleri nedeniyle daha düşük katılım göstermektedir (Tosun ve Tepeciklioğlu, 2014:499-500). Ülkelerin genel ve yerel seçim sonuçlarına bakıldığında bu tablo kendini büyük ölçütü hissettirmektedir. Cinsiyetin siyasal yaşama ve katılıma etkisi çalışmanın ileri kısımlarında detaylı incelenmektedir.

Türkiye'de yerel siyaset ve seçimlerde kadın katılımını artırmaya yönelik katkı sağlayacak araçları; "siyasal partilerin kadın kolları, yerel seçimlerde kadın aday kotalarl, kent konseyi ve meclisleri, mahalle muhtarlığı" (Sancar, 2018:139) şeklinde sıralamak mümkündür. Yan kuruluş olarak görülen siyasal parti kadın kollarının, yerel düzeyde sosyal organizasyonlar düzenleyerek siyasal destek oluşturmalarının yanı sıra seçim dönemlerinde kapı kapı dolaşıp oy isteme gibi yoğunlaşan görevleri vardır. Burada görev yapan kadınların parti yönetim kademelerine, yerel ve ulusal meclise temsilci olarak geçişleri sınırlı; karar organlarında söz yetkileri en alt düzeydedir (KA-DER, 2004:84). Diğer araç olarak Kota ise, eksik cinsiyet temelli temsilin alt sınırını göstermektedir. Siyasal karar mekanizmalarına seçileceklerin tespitinde uygulanmakta olan seçim usullerine özel hükümlerin eklenmesi suretiyle kadınlara belli oranlarda yer verilmesini (Kılıç, 2000:17) ifade ederken; karar alma aşamalarında ise yalnızca tek bir cinsin etkin olmasının önüne geçmek, cinsler arasında eşitliğin sağlanması maksadıyla yürürlüğe konmaktadır. "Temsilde eşitlik" bağlamında etkili bir araç olarak yerel siyasette uygulanması gerekmektedir. Kadın konseyi ve meclisleri, sürdürülebilir kalkınmanın yerelleşmesi hususunda yerel yönetimlerin yönetişim, katılım ve demokrasi alanlarında yapılandırılması amacıyla kurulan kent konseylerinde, kadın meclisi kurulması (Sancar, 2018:140) söz konusudur. Bu meclisler, kadınların yaşadıkları yer hakkında görüş beyan edebildikleri, proje sunabilecekleri bir örneği teşkil etmektedir. Kadının konumunun yükselmesi, siyasal ve toplumsal alandaki pek çok konuda katılıma, tartışma olanağı sunması kent konseyi kadın meclislerinin önemini ortaya koymaktadır. Mahalle Muhtarlığ l, kadına en yakın yerel yönetim 
organı olduğundan, yaşanılan yerdeki asayiş, düzen, sorunlar ve bunlara yönelik çözümler açısından kayda değer bir organ vazifesi görmektedir. 1930'lu yılda kazanılan bu hak, günümüzde temsil açısından çok geride seyretmekle birlikte, kadınların yerel siyasette var olduklarını göstermesi bakımından son derece önemlidir.

Temsil ve kurumları Orta Çağ'da ekonomik/toplumsal değişim sonucu beliren ihtiyaçları karşılamak üzere ortaya çıkmaktadır. Dahl'ın (1993:29) ifadesiyle, "demokrasinin bir icadı olarak değil de, Orta Çă̆ monarşik, aristokratik devletlerin bir kurumu şeklinde” gelişmektedir. Söz konusu dönemde yetkinin devredildiği kişinin, kurulun ve temsilcinin seçilmiş olması gerekli değildir. İmparator ve onun soyundan gelen kimselerin sahip olduğu temsil yetkileri ellerinden alınamaz. Süreklilik hakkının ifadesi olan temsil, monarşik yönetimi dahi meşru kabul etmektedir (Sartori, 1996:31). 18. ve 19. yüzyılda aktif bir kullanım alanı bulan kavram, bu günkü anlamıyla 13. ve 14. yüzyılda ortaya çıkmaktadır. Orta Çağ' da temsil kavramı, hak/görev açısından herhangi bir kişi ya da topluluk yerine davranış sergilemek anlamında kullanılmaz (TDK, 2005:1780). Temsil kavramı günümüzde Romalıların kullandığ1 “repraesentare” sözcügünden türetilmektedir. Bundan evvel ise mevcut olmayan bir şeyin yazılı bir şekilde oluşturulması anlamına gelmekteydi. Günümüzde kabul görmüş şekliyle temsil kavramı, bazı kurum/kurul/kişilerin bir başka kişi/kurum/sosyal sınıf adına davranışta bulunarak, onlar adına karar alma anlamında kullanılmaktadır (Örs, 1997:25).

Literatür incelendiğinde temsil kavramının pek çok tanımının yapıldığı görülmektedir. Genel kabule göre kavram, aktif olarak bulunmayan aracı kimseleri; gruplar, soyutlamalar vasıtasıyla var duruma getirmeyi ifade etmektedir (Pitkin, 1995:358). Birch (1971:15) temsil kavramının üç farklı kullanımına dikkat çeker; temsilcilerin çıkarlarını korumak, seçilen kişi, meclisleri ve bir sınıfin olağan kişi/gruplarını tanımlamak. Tarihsel aşamada Locke, Mill, Burke, Rousseau, Adams, Hobbes vb. filozofların temsilin işlev/geçerliliği hususunda farklı yaklaşımlar geliştirdiği görülmektedir (Bulut ve Tanıyıcı, 2008:172). Locke temsilin varlığına dikkat çekerek, temsile dayanmayan vergilenmenin zorbalık olduğunu ifade etmektedir. Adams seçimle meydana gelen meclisin her yönüyle halkı yansıtması gerektiğini savunmaktadır. Aynı düşünceyi paylaşan Burke, temsilci olarak seçilen organın özü itibariyle ulusu yansıtması gerektiğini dillendirmektedir. Mill ise katılımın geniş olduğu, toplumu tüm gereklerinin yansıtıldı̆̆ 1 yönetime büyük önem vermektedir (Çitçi, 1989:18-19). Söz konusu örnekleri çoğaltmak mümkün olmakla birlikte, bu yaklaşımların özünü, halk gibi düşünerek onun içinden gelen küçük bir azınlığın onun adına karar alması ve uygulaması (Bulut ve Tanıyıc1, 2008:172) oluşturmaktadır.

Demokratik rejime dayalı siyasal sistemlerde halk egemenliği ön koşuldur. Sartori'nin (1996:31) ifade ettiği gibi, "temsil demokrasinin temel ilkelerinden kabul edilen eşitliğin, siyasal sisteme seçimler vasitasıyla" uygulanmasını içermektedir. Tüm partilerin benzer koşullarda katılımına dayanan özgür seçimler, temsilin düzenli aralıklarla devredilmesinden öte iktidarın hakkıyla ortaya çıkmasını sağlamaktadır. Günümüzde temsil edilen tarafindan, temsilciye sunulan kendi adına davranma yetkisi, demokrasinin temelini oluşturur. Böylece temsil edilen adına yönetim görevini ifa edecek organ meydana gelerek, halkın doğrudan katılımının gerçekleşemediği durumda demokrasinin işlemesine yardımcı olmaktadır (Arasl1, 1972:10). Seçimlerin serbest/özgür olması, temsilcilerin belirli periyotlarda değiştirilebilme hakkının saklı tutulması demokrasinin işlerliği açısından ayrıca önem arz etmektedir. Heywood'un (2007:353) ifade ettiği gibi "temsilin amacını gerçekleştirebilmesi için, rekabete dayal, adil ve serbest, evrensel oy hakk bağlaminda yerine getirilmesi" gerekmektedir. Burada unutulmaması gereken, egemenliğin geçici devrinin söz konusu olduğudur. Bu sistemde, toplum içindeki farklı grupların temsiline imkân verilmelidir. Kadın, engelli, yaşlı, çocuk vb. dezavantajlı grupların temsil mekanizmasında görünür olmasına dikkat edilmeli, farklı çıkar gruplarının, özellikle STK temsilcilerinin, mecliste yer alması sağlanmalıdır.

Türkiye'de kadınların siyasette yer bulamamaları, temsil hakkını eşit bir şekilde kullanamamalarına dair pek çok neden vardır. Bunlar; ataerkil toplumsal ve kültürel yapı, siyasal alanda eril tahakküm, kadın, erkek arasındaki eşitsizlikler, siyasal partilerin yapısı, siyasal sistem ile işleyişi, siyasal ilgi ve bilinç, kadınların siyasal alanın vitrini olarak görülmesi şeklinde sıralamak mümkündür.

Ataerkil toplumsal, kültürel yapının biçtiği roller kadını özel alana hapsederken, erkeğe kamusal alanda geniş bir özgürlük olanağı sunmaktadır. Kadının rolü anne, eş, çocuk yetiştirme, ev işleri olarak özel alana konumlandırılırken; erkek ev dışı faaliyetlerin tümüne kolayca ulaşabilmektedir. Bu durum erkeğin kadına oranla siyasal alana katılma, beceri sahip olma ve kaynaklara ulaşımının hem daha fazla, çeşitli hem de kolay olmasını sağlamaktadır (Türeli ve Çağlar, 2010:24). Cinsiyet bağlamında şekillenen iş bölümü kadının ücretsiz ev işçiliğine mahkûm edilmesi, ekonomik olarak erkeğin gerisinde kalmasını beraberinde getirmektedir. Oğlan çocuğunun soyun devamı olarak görülmesi, kızın ilerde evlenerek ele karışacağı zihniyeti sosyo-ekonomik olarak kadının geri kalmasının belli başlı faktörüdür. Bu durum kadını erkeğe bağımlı kılarak, pek çok alanda olduğu gibi siyasal alanda onun arka planda kalmasına neden olmaktadır. Mevcut siyasal yapı erkeğin siyasete 
katılımında belli şartlar sunmazken; kadının temsilci seçilebilmesi için onlardan daha yetenekli, iyi eğitimli olması (Pınarcıoğlu, 2017:19) beklentisi, ikircikli bir durumun oluşmasına sebebiyet vermektedir.

Siyasal partilerin erkek egemen yapısı/söylemi kadının katılımını engelleyen bir başka faktördür. Toplumsal cinsiyetin erkeğe dayattığ para kazanmak, rekabet etme, güçlü/kuvvetli olma vb. roller siyasal alana taşınarak, bunların egemen değerler olarak görülmesine neden olmaktadır. Bu durum anne olma, çocuk yetiştirme rolleri yüklenen " $k a d ı n l ı k$ " değerlerine ters düşerek siyasetten uzak kalınmasını beraberinde getirmektedir (Sancar Üşür, 2000:208). Kadının simgesel olarak “vitrin” görevi üstlendiğini vurgulayan Tekeli (1983:213-214), Cumhuriyetin kadına sunduğu temel hakların en temel amacının rejimin demokratikleștirilmesi olduğunun altını çizmektedir. Kadın siyasette aktif bireyler olarak değil de "vitrin" olarak yer alması, yetersiz temsilin nedenini böylece göstermektedir. Kadın modernleşmeyle eş tutularak, bütün tartışmalar onun sosyal, siyasal ekonomik görünürlüğünün batılılaşmanın en büyük simgesi olması gerekçesiyle yapılmaktadır.

Seçim sistemlerinin kadın temsiline etkisi, dünyada nispi temsil sisteminin uygulandığ 1 ülkelerde, çoğunluk sistemini uygulayanlara göre daha yüksek kadın temsil oranına sahip oldukları görülmektedir. Nispi temsil sisteminin uygulandığı ülkelerin ulusal meclislerinde kadın temsilcilerin daha fazla olduğu göze çarpmaktadır (Pınarcıŏglu, 2011:59). Diğer faktör ise kadına yönelik ataerkil toplumun dayatmaları ekonomik, eğitim seviyesinin düşüklüğüne, bu durum teknik açıdan bilgi yetersizliğine, akabinde özgüven eksikliğine neden olmaktadır. Siyasal partilerin aday belirlemede kullandıkları önseçim, örgüt ve merkez yoklama gibi usuller bir diğer etken olarak karşımıza çıkmaktadır. Siyasal kültür, bilinç, ilgi gibi kavramlar da aynı şekilde egemen olan erkeksi siyasal yapının ürününü yansıtmaktadır.

\subsection{Toplumsal Cinsiyet ve Bileşenleri Olarak “Cinsel Kimlik, Cinsiyet Rolleri, Eşit(siz)liğ̈i/Ayrımcılı̆̆ı”"}

İnsanların dünyada var olma durumlarını anlamlandırmak maksadıyla sınıf, yaş, statü vb. gruplara ayrılmaktadır. $\mathrm{Bu}$ gruplardan yalnızca birini oluşturarak davranış biçimlerini, yaşam standartlarını şekillendirerek cinsiyet olgusu kapsamına giren, kadın ve erkek kavramı olduğu görülmektedir.

"Cinsiyet (Sex)" terimi, kadın ve erkek olmanın biyolojik yönüne, yapısına karşılık gelmektedir (Dökmen, 2012:19). Kadın, erkek cinsiyeti; maskülen (erkeksilik), feminen (kadınsılık) toplumsal cinsiyet kategorilerini ifade etmektedir. "Toplumsal cinsiyet (gender)", cinsler arası fiziksel farklılıktan ziyade erkeklik ile kadınlık özelliklerinin toplumsal biçimde oluşturduğu özelliklerden meydana gelerek (Giddens, 2000:104), toplumsal alandaki münasebetleri şekillendiren bir kavramdır (Scott, 2007:11). Savran (2004:235) kavramın; hem ayrımc1, baskıya dayalı eşitsiz bir toplumsal düzene verilen isim ve ilişkinin taraflarını ifade eden kategori olduğunu hem de bunların davranışsal, psikolojik niteliklerine gönderme yaptığını savunmaktadır.

Toplum tarafından kadınlık ve erkeklik olarak biçilen rolleri meydana getiren kalıp yargıları vardır. Bütün toplumlar erkeklerin, kadınların, erkek ve kız çocuklarının davranışlarını kontrol eden cinsiyet rollerini belirlemektedir (Kite, 1996:361). Başka bir ifadeyle toplumsal cinsiyet rolleri, toplumun kadın, erkekten cinsiyetleri bağlamında beklediği davranış kalıplarıdır (Uluocak vd. , 2014:7). Toplumsal normlar bağlamında şekillenen toplumsal cinsiyette kadına, erkeğe biçilen roller birbirinden farklıdır. Çünkü toplumun umumi yapısı ve himaye ettiği değerler her iki cinse de farklı roller yüklemektedir.

Söz konusu roller özellikle mekânsal, özel ve kamusal alan, ayrımlaşmasında kendini göstermektedir. Söz konusu ayrımlaşma, kadını ev içerisine bağımlı kılan yani özel alana konumlandıran; erkeği kamusal alanda özgür ve egemen kılan ritüellerin ön kabulüne dayanmaktadır. Öncelikle "iyi kız çocuğu, abla ve kardeş"; sonrasında "iyi eş, anne" olması arzu edilen kadın, bu şekilde biçilen rol kalıplarının zorunluluğu altında ezilmektedir (Oglesby ve Hill, 1993:717). Eğitim alanından siyasete, çalışma yaşamından sivil toplum örgütlenmesine kadar kamusal alanda cereyan eden bu görünüm, erkek ve kadın arasında cinsiyete dayalı eşitsizlik/ayrımcılık oluşturmaktadır (Bhasin, 2003:3). Kısaca, toplumsal cinsiyet kavramı toplumsal farklılıklara vurgu yaptığı kadar eşitsizliği de içermektedir.

"Toplumsal cinsiyet eşitliği " kavramıyla, kadın ve erkek arasındaki farkların, toplumdaki rollerin eşit öneme sahip oluşunun kabul gördüğü anlatılmaktadır. Kavram, cinsiyetler arasındaki eşitsiz güç iliş̧isine neden olan yapı/kurumların nasıl değiştirileceği, onlar arasında değerler ve öncelikler bağlamında daha iyi bir dengenin ne şekilde kurulacağını belirtmektedir (Civelik, 2014:2). Tuskan (2012:448) toplumsal eşitlik anlayışının sağlanması için yapılması gerekenleri sıralamaktadır. Bunlar; kadınların eğitilerek, kamusal alanda katılmalarında öncelik tanınması, kadına yüklenen rollere yönelik önyargılarla savaşılması, mesuliyetlerin paylaşılması, ailedeki kararların hep beraber alınması, sorumluluk, hak, oğlan, kız çocuk yetiştirmede eşitliğin 
sağlanması, kadın istihdamının ve toplumsal olarak görünürlüğünün desteklenmesi, kadına yönelik şiddetle/ayrımcılıkla mücadele, eşit firsat sağlanarak olumlu ayrımcılığın uygulanma alanı sağlanması şeklindedir.

Toplumsal cinsiyet eşitsizliği/ayrımcıllı̆ mevki iktidar farklılıklarını ifade etmektedir. Biyolojik olarak kız/oğlan şeklinde doğan çocuklar, toplum tarafindan onlara yüklenen statü, roller ve cinsiyet kalıp yargıları nedeniyle söz konusu alanda değişik işlev ve konumda olmalarına sebebiyet vermektedir (Giddens, 2000:506-526). Kısaca Berkay'ın (2009:16) ifade ettiği gibi kavram "cinsler arası eşitsiz güç ilişkilerine” dayanmaktadır. Kişilerin cinsiyetle ilgili temel kabullerinin toplumsal kurumlar tarafından belirlenerek kadın aleyhinde cinsiyet ayrımcılığına neden olduğu belirtilmiştir. (Balkır, 2012:69). Özetle toplumsal cinsiyet ilişkileri, pek çok alanda erkeklerin daha hâkim olduğunu; kadınların genel olarak ikinci konuma itilmek suretiyle meydana gelen eşit olamayan güç ilişkilerini içermektedir. Erkeğe ve işlerine verilen değer/üstünlük, kadınınkilerinden daha önemli/önceliklidir. Tarihsel olarak bakıldığında erkek egemen bu yaklaşımla toplumun şekillendirildiği görülmektedir. Bu kabul ediş toplumun bütünde uzlaşmayı beraberinde getirir. Söz konusu durum politik yapılarda kendini göstermektedir. Erkek üzerinden şekillenen bu düzen toplumsal cinsiyet eşitsizliğine/ayrımcılığına neden olmaktadır.

Kısaca ataerki yapı düzeninde özellikle aile içerisinde beliren eşitsizlik/ayrımcılık kız, erkek çocuk doğuşuyla kendini belli etmektedir. Erkek çocuğu doğan aileler, kız sahibi olanlara göre daha çok mutlu olarak kendilerini kıvançlı hissetmektedir. Anne gözetiminde kız çocuğu kendine biçilen ev içi vb. rolleri öğrenerek yetiştirilirken; erkek babayla ev dışında güç gerektiren işlere yönlendirilmek suretiyle büyütülmektedir. Kız çocuğunun evlenip, yuvadan uçacağı; erkeğin soyun devamı olarak görülmesi eşitsizliğin/ayrımcılı̆̆ın derinden hissedilerek, eğitimden iş yaşamına kadar pek çok alanda kız çocuğunun, kadının oğlan, erkek karşısında ikincil konumda kalmasına eşit şartlarda mücadele edememesine neden olmaktadır. Bunlardan sadece birini teşkil eden siyasal alan incelendiğinde, katılım hususunda kadının erkekle eşit haklara sahip olduğu görünse de uygulama açısından eşitsizliğin ve ayrımcılığın varlığı kendini hissettirmektedir. Gerek ulusal gerekse de yerel siyasetteki kadın temsil oran ve sayıları incelendiğinde, bu alandaki yokluk durumu kolayca görülmektedir.

\section{YEREL SIYYASETTE KADIN TEMSILININ "YOKLUK DURUMU"NUN TARİHSEL UĞRAKLARI}

Cumhuriyet dönemi devrimleri kadın hakları bakımından bir milat özelliği taşımaktadır. Cumhuriyet ilanıyla oluşturulan demokratik ve laik yapıda kadın; eğitim, siyaset, ekonomik alanda görünür olmaya başlamaktadır. Kadınlar, 1924'te Tevhid-i Tedrisat, 1925'te Klllk Klyafet ile 1926 tarihinde kabul edilen Medeni Kanunla sosyal haklar elde etmektedir (Gökçimen, 2008:9). Kadınlar 1930 yılında çıkan Belediye Kanunuyla, seçimlerde seçmen ve aday olarak ilk siyasal hak edişlerine kavuşmaktadır. 1933 yılında Köy Kanununda yapılan değişiklikle muhtar olma, ihtiyar heyeti içinde vazife almak için yasal dayanağa ulaşılmaktadır. 1934'te kendi mücadeleleriyle kazandıkları milletvekili seçme ve seçilme hakkı (Türeli ve Çağlar, 2010:21) siyasal açıdan doruğa ulaşımın göstergesini teşkil etmektedir.

Yerel yönetimler bağlamında bakıldığında 1930 yılındaki seçimlerde SCF ve CHF'nin belediye başkanlığı, belediye meclis üyeliği ve muhtarlık için kadın aday gösterdiği görülmektedir. İstanbul'dan SCF iki, CHF yedi kadın adayı vardır. SCF kendini seçim öncesi fesih ettiğinden kadınların seçilmesi olanaksız hale gelmektedir. CHF'ten dört aday belediye meclisinde yer almaktadır. Bunun yanı sıra kadınlar Kastamonu, İzmir, Ankara, Burdur, Bursa, Antalya, Rize, Muş, Kayseri, Trabzon, Aydın illerinde de belediye meclisine girmektedir. 1934, 1938, 1942 yerel seçimlerinde kadınlar tüm yurtta aday olarak gösterilmektedir. 1946 yılında çok partili hayata geçildiği dönemde belediye başkanı, meclis üyeliği kadın aday sayısı düşüşe geçmektedir. Bu azalma 1960-80 döneminde yerel siyasette kadın temsiline yansır. 1980 sonrasında söz konusu durum ivme kazanmaktadır. 1990'larda ilk kadın başbakan Tansu Çiller'in rol model olarak görünürlük kazanması önemli bir gelişmedir (Üste, 2017:103). Yerel siyasette 1990'lı ve sonrasındaki yıllara bakıldığında, kadınların oransal açıdan erkeklerden çok geri bir sıralamada yer aldığı görülmektedir. Tablo l'de 1968'den 1994 yılı dâhil, seçilen kadın belediye başkanlarına yer verilmektedir.

1963 yılı öncesinde arşivleme yönteminin kısırlı̆̆ yılında Sadiye Hanım Artvin Yusufeli/Kılıçkaya Belediyesi ve 1950'de Müfide İlhan) zikredilmekle beraber, tam olarak kanıtlanmış bir çalışma olmadığından gerekli verilere ulaşılamamaktadır. 
Tablo 1. 1968’den 1994 Seçimlerine Kadar Kadın Belediye Başkanı Sayısı ve Oranları

\begin{tabular}{|c|c|c|c|}
\hline $\begin{array}{c}\text { SEÇIM } \\
\text { YILI }\end{array}$ & $\begin{array}{c}\text { TOPLAM BELEDIYE } \\
\text { SAYISI }\end{array}$ & KADIN & $\begin{array}{c}\text { ORAN } \\
(\mathbf{\%})\end{array}$ \\
\hline $\mathbf{1 9 6 8}$ & 1238 & $\mathbf{4}$ & $\mathbf{\% 0 , 3}$ \\
\hline $\mathbf{1 9 7 3}$ & 16201 & $\mathbf{5}$ & $\mathbf{\% 0 , 0 3}$ \\
\hline $\mathbf{1 9 7 7}$ & 1710 & $\mathbf{5}$ & $\mathbf{\% 0 , 3}$ \\
\hline $\mathbf{1 9 8 4}$ & 1692 & - & $\mathbf{\% 0}$ \\
\hline $\mathbf{1 9 8 9}$ & 1976 & $\mathbf{2}$ & $\mathbf{\% 0 , 1}$ \\
\hline $\mathbf{1 9 9 4}$ & 2695 & $\mathbf{9}$ & $\mathbf{\% 0 , 3}$ \\
\hline
\end{tabular}

Kaynak: Aslan, 2009:49-65'ten derlenip, tablolaştırıldı.

Kadın belediye başkanlarının partiler bağlamında dağılımı ise; 1968'te 3 CHP, 1 AP; 1973'te 1 CHP, 1 AP, 3 Bağımsız; 1977'te 1 CHP, 3 AP, 1 Bağımsız; 1989'da 2 SHP'den; 1994'te 2 Bağımsız, 2 SHP, 3 DYP, 2 ANAP şeklindedir. 1977 seçimlerinde 12 Eylül 1980 darbesi nedeniyle birçok belediye başkanlığında görev değişikliğine gidilmektedir. Bu dönemde üç kadın MGK tarafından İçel, Çanakkale ve Afyon'da belediye başkanlığı görevine atanmaktadır. 1984 yılında belediye başkanı seçilen kadın adayın olmadığı göze çarpmaktadır.

Tablo 2. 1999 ve 2004 yılı Yerel Seçimlerini Kazanan Kadın ve Erkek Sayısı/Oranları

\begin{tabular}{|c|c|c|c|c|c|c|c|c|c|c|}
\hline \multirow{3}{*}{ Seçilmişlik Türü } & \multicolumn{5}{|c|}{1999 Yılı Yerel Seçimleri } & \multicolumn{5}{|c|}{2004 Yılı Yerel Seçimleri } \\
\hline & \multirow{2}{*}{ Toplam } & \multicolumn{2}{|c|}{ Kadın } & \multicolumn{2}{|c|}{ Erkek } & \multirow{2}{*}{ Toplam } & \multicolumn{2}{|c|}{ Kadın } & \multicolumn{2}{|c|}{ Erkek } \\
\hline & & Sayı & Oran & Sayı & Oran & & Sayı & Oran & Sayı & Oran \\
\hline Belediye Başkanı & 3.215 & 18 & $\% 0,6$ & 3.197 & $\% 99,4$ & 3.225 & 18 & $\% 0,6$ & 3.207 & $\% 99,4$ \\
\hline Belediye Meclisi Üyesi & 34.084 & 541 & $\% 1,6$ & 33.543 & $\% 98,4$ & 34.477 & 817 & $\% 2,4$ & 33.660 & $\% 97,6$ \\
\hline İl Genel Meclis Üyesi & 3.122 & 44 & $\% 1,4$ & 3.078 & $\% 98,6$ & 3.208 & 57 & $\% 1,8$ & 3.151 & $\% 98,2$ \\
\hline Toplam & 40.421 & 603 & $\% 1,49$ & 39.818 & $\% 98,51$ & 40.910 & 892 & $\% 2.18$ & 40018 & $\% 97.82$ \\
\hline
\end{tabular}

Kaynak: www.ysk.gov.tr adresinin 18.04.1999 ve 28.04.2004 “Mahalli İdareler Seçim Sonuçlarl” kısmından derlenip, tablolaştırıldı.

Tablo 2'de 1999 ve 2004 yılı "seçilme" düzeyinde kadın, erkek temsiline yer verilmektedir. 1999 y1lında yapılan seçimlerde, "seçilme" düzeyinde temsil incelendiğinde; belediye başkanlığında 3.215 kazanan adaydan 18 'i (\%0.6), belediye meclis üyeliği 34.084 seçilenden 541 'inin (\%1.6), 3.122'den ise 44'ü (\%1.4) toplamda ise 40.421 kişiden 603'ünün (1.49) kadın olduğu görülmektedir. 2004 yerel seçimlerine bakıldığında, 3.225'den $18^{\prime}$ inin $(\% 0.6), 34.477^{\prime}$ den $817^{\prime} \operatorname{sinin}(\% 2.4)$, 3.208'den 57'sinin (\%1.8) toplamda 40.910 kişiden 892'sinin (2.18) kadın temsilcidir.

Söz konusu iki yerel seçim sonuçları karşılaştırıldığında, 1999 yılında seçilen 3.215 ve 2004'te kazanan 3.225 belediye başkanının sadece 18 'i $(0,6)$ kadın olması yerel siyasette yetersiz temsilin varlığını göstererek, zaman geçse de hiçbir değişikliğin olmadığını gözler önüne sermektedir. Belediye meclis üyeliğindeki $541(\% 1,6)$ olan temsilin $817(\% 2,4)$ yükselerek \%51 oranında; il genel üyeliğinde ise $44(\% 1,4)$ 'ten $57(\% 1,8)$ 'e çıkarak \%30'luk bir artış seviyesi yakaladığı görülmektedir. Fakat oranların 1999 yılında \%0,6 ve \%1,4, 2004'te \%0,6 ile \%1,8 arasında seyretmesi genel toplam içinde sonucun değişmemesi Türkiye'deki kadın temsili yokluğunun açık bir göstergesidir.

Tablo 3'deki verilen 2009 ve 2014 yerel seçimi verileri doğrultusunda hem "aday olma" hem "seçilme" kriterleri bağlamında kadın temsili incelendiğinde, büyükşehir belediye başkanlığına aday olan 218 ve 488 kişiden kadın sayısı, oranları sırasıyla 21 (\%10), 44 (\%9) olduğu görülmektedir. Burada kadın aday sayısı artarken oransal bir azalış gözükmektedir. İl genel meclis üyeliğinde 31.083 ve 6.474 kişiden seçim yılı sırasına göre 2.576'sı (\%8) ile 538'i (\%8) kadın adaydır. Kadın aday sayısında artış yaşanırken, oranın sabit kaldığı görülmektedir. Belediye başkanlığı düzeyinde 15.569 ve 9.186 olan adaydan 554 (\%6), 544’ü (\%4) kadındır. 
Belediye meclis üyeliğinde 179.911 ve 99.707 olan adaydan 10.811 (\%6), 11.901’i (12) kadın olduğu göze çarpmaktadır. Burada sayı ve oransal bir artış yaşanmaktadır.

Tablo 3. 2009 ve 2014 Yılı Yerel Seçimi Kadın, Erkek Aday ve Kazananların Sayısı/Oransal Dağııımı

\begin{tabular}{|c|c|c|c|c|c|c|c|c|c|c|c|}
\hline \multirow{3}{*}{$\begin{array}{l}\text { Seçilmişlik } \\
\text { Türü }\end{array}$} & \multirow{3}{*}{$\begin{array}{c}\text { Seçim } \\
\text { Yılı }\end{array}$} & \multicolumn{5}{|c|}{ Seçime Katılan Kadın/Erkek Sayı ve Oranları } & \multicolumn{5}{|c|}{ Seçimi Kazanan Kadın/Erkek Sayı ve Oranları } \\
\hline & & \multirow{2}{*}{ Toplam } & \multicolumn{2}{|c|}{ Kadın } & \multicolumn{2}{|c|}{ Erkek } & \multirow{2}{*}{ Toplam } & \multicolumn{2}{|c|}{ Kadın } & \multicolumn{2}{|c|}{ Erkek } \\
\hline & & & Sayı & Oran & Sayı & Oran & & Sayı & Oran & Sayı & Oran \\
\hline \multirow{2}{*}{$\begin{array}{c}\text { Büyükşsehir } \\
\text { Belediye } \\
\text { Baskanı } \\
\end{array}$} & 2009 & 218 & 21 & $\% 10$ & 197 & $\% 90$ & 16 & 0 & $\% 0$ & 16 & $\% 100$ \\
\hline & \begin{tabular}{|l|}
2014 \\
\end{tabular} & 488 & 44 & $\% 9$ & 444 & $\% 91$ & 30 & 3 & $\% 10$ & 27 & $\% 90$ \\
\hline \multirow{2}{*}{$\begin{array}{c}\text { İl Genel Meclis } \\
\text { Üyesi }\end{array}$} & 2009 & 31.083 & 2.576 & $\% 8$ & 28.507 & $\% 92$ & 3.281 & 115 & $\% 4$ & 3.166 & $\% 96$ \\
\hline & 2014 & 6.474 & 538 & $\% 8$ & 5.936 & $\% 92$ & 1.258 & 61 & $\% 5$ & 1.197 & $\% 95$ \\
\hline \multirow{2}{*}{$\begin{array}{l}\text { Belediye } \\
\text { Başkanı }\end{array}$} & 2009 & 15.569 & 554 & $\% 4$ & 15.015 & $\% 96$ & 2.931 & 26 & $\% 1$ & 2.905 & $\% 99$ \\
\hline & 2014 & 9.186 & 544 & $\% 6$ & 8.642 & $\% 94$ & 1.364 & 37 & $\% 3$ & 1.327 & $\% 97$ \\
\hline \multirow{2}{*}{$\begin{array}{c}\text { Belediye } \\
\text { Meclis Üyeliği }\end{array}$} & 2009 & 179.911 & 10.811 & $\% 6$ & 169.100 & $\% 94$ & 32.475 & 1.474 & $\% 5$ & 31.001 & $\% 95$ \\
\hline & 2014 & 99.707 & 11.901 & $\% 12$ & 87.806 & $\% 88$ & 20.538 & 2.206 & $\% 11$ & 18.332 & $\% 89$ \\
\hline \multirow{2}{*}{ Toplam } & 2009 & 226.781 & 13.962 & $\% 6$ & 212.819 & $\% 94$ & 38.703 & 1.615 & $\% 4$ & 37.088 & $\% 96$ \\
\hline & 2014 & 115.855 & 13.027 & $\% 11$ & 102.828 & $\% 89$ & 23.190 & 2.307 & $\% 10$ & 20.883 & $\% 90$ \\
\hline
\end{tabular}

Kaynak: www.tuik.gov.tr adresinin 'Mahalli İdareler Seçim Sonuçları’’ kısmından derlenip, tablolaştırıldı.

Özetle "aday olma"' düzeyinde kadın temsiline bakıldığında, 2009 yılında 226.781 adaydan 13.962 (\%6); 2014 seçimlerinde 115.855 kişiden 13.027 'sinin (\%11) olduğu tabloda net verilerle gösterilmektedir. Sayısal olarak yakın rakamlar görülürken, oransal olarak \%4'lük bir artışa rastlanılmaktadır.

“Seçilme” düzeyi bağlamında incelendiğinde, 2009 yılında büyükşehir belediye başkanlığını kazanan 16 aday arasında kadın temsile rastlanmazken, 2014 seçimlerinde 30 kişinin 3'ünün (\%10) kadın temsilci olduğu görülmektedir. İl genel meclis üyeliğine seçilen 3.281 ve 1.258 kişiden 115 (\%4), 61'i (\%5); belediye başkanlığında 2.931 ile 1.364 'den 26 (\%1), 37 (\%3); belediye meclis üyeliğine seçilen 32.475 ve 20.538 kişiden 1.474'ü (\%5), 2.206's1 (\%11) kadındır. Toplamda 2009 ve 2014 yılında seçilen sirasiyla 38.703 ve 23.190 temsilcilin 2.307'si (\%10) ile1.615 (\%4) kadın olduğu bilgilerine ulaşılmaktadır. Bakıldığında hem rakamsal hem de oransal artış söz konusudur.

2014 yerel seçim sonuçlarına bakıldığında 2009 yılına oranla artış göze çarpmaktadır. Bu artışın nedeni 6360 sayılı Büyükşehir Belediye Kanunu bağlamında yapılan değişikliklerle doğrudan alakalıdır. Kapatılma sonucu azalan belde belediye ve il özel idareleri sayısındaki durum önemli bir faktördür.

2009 ve 2014 yerel seçim sonuçları incelendiğinde hem "aday olma” hem de "seçilme" düzeyinde kadın temsiline bakıldığında az da olsa artış olduğu görülmektedir. Fakat 2009 ile 2014 yılındaki seçimlerde toplamda "aday olma" düzeyinde sirasıyla \%6, \%11, "seçilme"' bağlamında \%4, \%10 olan kadın temsil oranları, erkeklere göre ne denli yetersiz seviyede kalındığını gözler önüne sermektedir. Son dönem seçim sonuçlarıyla kadının yerel siyasetteki temsil sorunsalı bir kez daha yinelenmektedir. Siyasetin erkek işi olduğu algısının, kadınların temsil hakkını kanunen alması üzerinden uzun zaman geçmiş olsa da varlığını hala koruduğu açıça ortadadir.

Tablo 4'deki veriler incelendiğinde, büyükşehir belediye başkanlığına aday olan kadın sayısı, 2014 yılına göre az iken, oransal olarak ise \%2'lik bir artış gözükmektedir. "Seçilme" düzeyinde $3(\% 10)$ olan temsil sayısı tekrarlanmaktadır. İlk genel meclis üyeliğine adaylık 2004'de 538 (\%8) iken, 2019'da 690 (\%8) olmaktadır. Oransal olarak değerde bir değişiklik olmadığı gözükmektedir. Seçilmede 61 (\%5) olan sayı ve oranın, 2019'da 48 'e (\%4) gerilediğine rastlanılmaktadır.

Belediye başkanlığı düzeyinde ise, "aday olma”' bağlamında temsil sayısı 2014 yılında 544 (\%6) iken, 2019'da 634'e (\%8) çıkmaktadır. "Seçilme"' noktasında 37 (\%3) olan sayı, oranda pek fazla değişiklik yaşanmayarak 38 (\%3) seviyesinde kalmaktadır. Belediye meclisi üyesi açısından kadın "aday'” sayısı, oranı 2014'de 11.901 (\%12) seviyesindeyken, son seçimde 14.485 (\%14) olduğu görülmektedir. "Seçilme”, bağlamında bakıldığında ise 2.206 (\%11) olan sayı ve oranın, 2019 yılı seçimlerinde 2.284 (\%11) olarak pek de değişmediği ortadadır. 
Tablo 4. 2019 Yılı Yerel Seçimi Kadın, Erkek Aday ve Kazananların Sayısı/Oransal Dağılımı

\begin{tabular}{|c|c|c|c|c|c|c|c|c|c|c|c|}
\hline \multirow{3}{*}{ Seçilmişlik Türü } & \multirow{3}{*}{$\begin{array}{c}\text { Seçim } \\
\text { Yılı }\end{array}$} & \multicolumn{5}{|c|}{ Seçime Katılan Kadın/Erkek Sayı ve Oranları } & \multicolumn{5}{|c|}{ Seçimi Kazanan Kadın/Erkek Sayı ve Oranları } \\
\hline & & \multirow{2}{*}{ Toplam } & \multicolumn{2}{|c|}{ Kadın } & \multicolumn{2}{|c|}{ Erkek } & \multirow{2}{*}{ Toplam } & \multicolumn{2}{|c|}{ Kadın } & \multicolumn{2}{|c|}{ Erkek } \\
\hline & & & Sayı & Oran & Sayı & Oran & & Sayı & Oran & Sayı & Oran \\
\hline $\begin{array}{c}\text { Büyükşehir Belediye } \\
\text { Başkanı }\end{array}$ & 2019 & 305 & 33 & $\% 11$ & 272 & $\% 89$ & 30 & 3 & $\% 10$ & 27 & $\% 90$ \\
\hline $\begin{array}{l}\text { İl Genel Meclis } \\
\text { Üyesi }\end{array}$ & 2019 & 8.719 & 690 & $\% 8$ & 8.029 & $\% 92.08$ & 1.272 & 48 & $\% 4$ & 1.224 & $\% 96$ \\
\hline Belediye Başkanı & 2019 & 7.953 & 634 & $\% 8$ & 7.319 & $\% 92$ & 1.359 & 38 & $\% 3$ & 1.321 & $\% 97$ \\
\hline $\begin{array}{l}\text { Belediye Meclis } \\
\text { Üyesi }\end{array}$ & 2019 & 102.337 & 14.485 & $\% 14$ & 87.852 & $\% 86$ & 20.745 & 2.284 & $\% 11$ & 18.461 & $\% 89$ \\
\hline Toplam & 2019 & 119.314 & 15.842 & $\% 13.28$ & 103.472 & $\% 86.72$ & 23.406 & 2.373 & $\% 10$ & 21.033 & $\% 90$ \\
\hline
\end{tabular}

Kaynak: www.tuik.gov.tr adresinin “Mahalli İdareler Seçim Sonuçlarl” kısmından derlenip, tablolaştırıldı.

Özetle, 2019 ve 2014 yılındaki yerel seçimler “aday olma ve seçilme” kriterleri bağlamında kadın temsili açısından kıyaslandığında sayısal ve oransal olarak birbirine yakın verilerin olduğu görülmektedir. Söz konusu temsil kriterleri özelinde 2019 y1lında toplamda \%13.28 ve \%10'luk dilimlerle, yerel siyasette hali hazırda tarihsel tekerrür misali tekrarlanan, yazg1 haline gelen "yokluğu ve yetersizliği" gözler önüne bir kez daha sermektedir.

\section{KADIN TEMSILII AÇISINDAN 31 MART 2019 YEREL SEÇİM SONUÇLARININ TRABZON İLI ÖRNEĞİ BAĞLAMINDA ANALIZİ}

Türkiye'nin kuzeydoğusunda yer alan Trabzon İli, 4.664 km'lik yüzölçüme sahip; batısında Giresun, güneyinde Gümüşhane ve Bayburt, doğusunda Rize İlleri ile çevrili bulunmaktadır. Merkez Ortahisar olmak üzere Akçaabat, Araklı, Arsin, Beşikdüzü, Çarşıbaşı, Çaykara, Dernekpazarı, Düzköy, Hayrat, Köprübaşı, Maçka, Of, Sürmene, Şalpazarı, Tonya, Vakfikebir, Yomra olmak üzere on sekiz beldeden oluşmaktadır. Trabzon İlinde belediyenin ilk ne zaman kurulduğu hakkında herhangi bir tarihsel dokümana rastlanmazken, 1869 yllında çıkarılan İl Yıllığı (Salname-i Vilayet-i Trabzon) incelendiğinde belediye yönetimine yer verildiği görülmektedir. 2014 yılına kadar il belediyesi statüsünde hizmet verirken, 30 Mart 2014 tarihinde büyükşehir belediyesi statüsü elde ederek sorumluluk alanını bütün il sınırlarını içine alacak (www.trabzon.bel.tr, 2019) şekilde genişletilmiştir.

Türkiye'nin en kalabalık yirmi yedinci ili olan Trabzon'un nüfusu 2019 y1lına göre, 808.974 olup; 400.723'ü $(49,53)$ erkek, 408.251'i $(50,47)$ kadından oluşmaktadır. Nüfusun yoğun olduğu yerler, \%40,60 Ortahisar ve $\% 25,56$ Akçaabat'tır. Diğer beldeler ise \%1'lik bir azalma dilimi göstermek suretiyle, sen az nüfus \%0,60 Köprübaşı, \%0,49 Dernekpazarı'nda yer almaktadır. Nüfusun yaş dağılımına bakıldığında dengeli bir dağılım dikkat çekmekte olup, en yoğun olarak \%7,27 oranında 35-38, \%7,25 oranında 15-19 ve en fazla \%7,96 oranında 20-24 yaş arası nüfusun (www.tuik.gov, 2019) olduğu görülmektedir.

\subsection{Araştırmanın Amacı}

Çalışmada, Trabzon İlinde 31 Mart 2019 tarihinde gerçekleştirilen mahalli idareler seçimleri bağlamında, başta büyükş̧ehir belediye başkanlığı seçimi olmak üzere merkez Ortahisar ile birlikte toplam 18 beldede belediye başkanlığı, belediye ve il genel meclis üyeliğine talip kaç kadın aday olduğunu ve seçime girenlerin kaçının seçildiğinin ortaya çıkarılması amaçlanmaktadır. Gerçekleştirilmek istenen başlıca hedefler ise;

$\checkmark$ Kadın temsilinin Trabzon İli bağlamında partiler özelinde istatistiksel verilerinin incelenmesi suretiyle kaç kadın aday gösterdiklerinin ortaya çıkarılması,

$\checkmark$ Kadın ve erkek temsilci oranının "adaylar ve seçilmişler" bağlamında araştırılması,

$\checkmark$ Türkiye'deki yerel siyasette kadın temsil oranının hâlâ yeterli düzeyde olmadığı savının sınanmasıdır. 


\subsection{Araştırmanın Kapsamı ve Sınırlılıkları}

Bu bağlamda öncelikle, Trabzon İlinde başta merkez olmak üzere on sekiz beldesinde 31 Mart 2019 tarihinde gerçekleşen mahalli idareler seçimlerine bağımsız katılan ve siyasi partilerce aday gösterilen erkek, kadın sayıları tespit edilmektedir. İkinci olarak seçime katılan adaylar içinden seçilen büyükşehir belediye başkanı, belde belediye başkanı, belde belediye meclis üyesi ve il genel meclis üyelerinin kadın ve erkek temsil oranları belirlenmektedir. 1999 ve 2004 y1lı yerel seçimlerine “aday olma” düzeyindeki istatistiki bilgilere TÜiK'ten ulaşılamadığı için YSK'dan elde edilen sonuçlarla söz konusu seçimlerin sadece "seçilme" kriteri bağlamındaki verilerine yer verilmektedir. Mahalle muhtarlığı ve azalıkları, köy muhtarı ile ihtiyar heyeti üyeliklerine yönelik bilgilere YSK, TÜİK veri tabanlarından ulaşılamadığından çalışmaya dâhil edilmeyerek, kapsam dışı bırakılmaktadır.

\subsection{Araştırmanın Yöntemi}

Betimsel analiz yöntemi, önceden belirlenen bir tematik çerçeveye bağlı kalınarak nitel verilerin işlenmesi suretiyle bulguların tanımlanarak, yorumlanması aşamalarını içeren bir analiz yaklaşımıdır. Betimsel analizde elde edilen veriler, ilkte belirlenen başlıklar/temalar altında özetlenerek, yoruma tabi tutulmaktadır. Söz konusu veriler, sorularına göre kategorilere ayrılmaktadır. $\mathrm{Bu}$ analiz şeklinde, veri kaynaklarından belli başlı alıntılar yapılarak, açıklamalarda bulunulması çalışmanın güvenirliliği bağlamında önem arz etmektedir. Söz konusu analiz yönteminin amacı, ham şekilde bulunan verileri okuyucuların anlayabilecekleri, kullanabilecekleri forma sokmaktır. Bu gayeyle oluşturulan veriler ilk olarak mantıki bir sıraya konmaktadır. Sonrasında yapılan sınıflandırmalar/betimlemeler yorumlanmak suretiyle sonuçlara ulaşılmaktadır. Son evrede ise yapılan yorumlar çerçevesinde gelecekle ilgili öngörülerde bulunulmak suretiyle yeni açlımlara (Yıldırım ve Şimşek, 2011: 268) varılmaya çalışılmaktadır.

Araştırmada, Trabzon İl/Belde ve Yüksek Seçim Kurulu'nun (YSK) ilan ettiği seçim sonuç/istatistiklerinin incelenmesi suretiyle kadın, erkek "aday olma ve seçilme" düzeyi bağlamında temsil sayı, oranı belirlenmektedir. Akabinde bu veriler 1şığında değerlendirmeler yapılmaktadır. Kadınların "aday olma ve seçilme" yüzdesini daha ayrıntılı belirlemek amacıyla asil, yedek ve kontenjan olmak üzere tüm adaylar tek tek incelenmektedir. Betimsel analiz yöntemiyle öncelikle listeler oluşturulmaktadır. Akabinde buradaki bilgiler tablolaştırılmaktadır. Aşağıdaki tablolarda yer alan rakamlar, her üç adaylık türünün tamamını içermektedir.

\subsection{Trabzon İlinde 31 Mart 2019 Yerel Seçimlerinde Kadın Temsili}

Çalışmanın bu kısmında, yukarıda ifade edilen sorunsal bağlamında Türkiye'deki yerel siyasette kadın temsilinin yeterli düzeye hala erişemediği tezinin sınanması maksadıyla Trabzon İli ve beldeleri özelinde, 31 Mart 2019 tarihinde gerçekleştirilen mahalli idareler seçim sonuçları analiz edilmektedir. Bu amaçla büyükşehir ve belde belediye başkanlığl, belde belediye/il genel meclis üyeliği için aday olanların cinsiyetleri bazında dağılımı tablolaştırılmaktadır. Bu tablolarda kadın, erkek adayların sayısı ve oranları ayrı ayrı gösterilerek, kadınların kaçının istedikleri makama seçildiklerine dair bilgiler verilmektedir.

\subsubsection{Büyükşehir Başkanlığı Seçimleri Düzeyinde Kadının İkircikli Durumu}

Trabzon Belediyesi, 30 Mart 2014 tarihinden bu yana büyükşehir belediyesi statüsüne sahip olarak sorumluluk alanı tüm il sınırlarını kapsamaktadır. 31 Mart 2019 tarihinde gerçekleşen yerel seçimlere partilerce gösterilen adaylara ait bilgilere Tablo 5'de yer verilmektedir.

31 Mart 2019 seçimlerinde Trabzon'da toplam 594.912 seçmenden 475.451'inin oy kullandığ , bunların 22.425 geçersiz/boş kabul edildiği ve oylamaya katılım oranının \%83,73 olduğu bilgilerine ulaşılmaktadır. AK Parti/Milliyetçi Hareket Partisi (MHP)'nin Cumhur İttifakı adayı Murat Zorluoğlu, İyi Parti/CHP (Cumhuriyet Halk Partisi)'nin Millet İttifakınınki Atakan Atasoy'dur. Bunların yanı sıra DSP (Demokratik Sol Parti), SP (Saadet Partisi), BTP (Büyük Türkiye Partisi), TKP (Türkiye Komünist Partisi), VP (Vatan Partisi), DP (Demokrat Parti) ve bağımsız olmak üzere dokuz aday seçimlere katılmaktadır. Sadece iki partinin, VP ve DSP, kadın belediye başkan adayı olduğu görülmektedir. 
Tablo 5. 31 Mart 2019 Yerel Seçimlerinde Partilerin Büyükşehir Başkan Adayları ve Bilgileri

\begin{tabular}{|c|c|c|c|}
\hline \multirow{2}{*}{ Parti Adı / Bağımsız } & \multicolumn{2}{|c|}{ Büyükşehir Belediye Başkanı Adayları 31 Mart 2019 } \\
\cline { 2 - 4 } & Aday Adı Ve Soyadı & Mesleği & Öğrenim Durumu \\
\hline Saadet Partisi (SP) & Hasan SAKA & İş Adamı & Üniversite/Yüksekokul \\
\hline Bağımsız Türkiye Partisi (BTP) & Haydar BEKTAŞOĞLU & Eğitimci & Üniversite/Yüksekokul \\
\hline Türkiye Komünist Partisi (TKP) & Özgür Murat BÜYÜK & Avukat & Üniversite/Yüksekokul \\
\hline Vatan Partisi (VP) & İnci GÜNGÖR & Mimar & Üniversite/Yüksekokul \\
\hline Adalet ve Kalkınma Partisi (Ak Parti) & Murat ZORLUOĞLU & Memur & Üniversite/Yüksekokul \\
\hline Demokrat Parti (DP) & Ercan ŞILBIR & İ İnsanı & Ortaokul/Lise \\
\hline İyi Parti & Atakan AKSOY & İnşaat Yüksek Mühendisi & Üniversite/Yüksekokul \\
\hline Demokratik Sol Parti (DSP) & Hadiye SOLMAZ & Emekli & Ortaokul/Lise \\
\hline Bağımsız & İbrahim TOPUZ & Serbest & Ortaokul/Lise \\
\hline
\end{tabular}

Kaynak: www.ysk.gov.tr adresinin “31.03.2019 Mahalli İdareler Genel Seçimleri”’ kısmından derlenip, tablolaştırıldı.

Söz konusu seçimde "aday olma" düzeyinde temsil sayı ve oranları; 7'sı $(\% 77,78)$ erkek, 2'si $(\% 22,2)$ kadın olmak üzere toplam 9'dur. Seçim sonucunda Ak Parti 307.167 (\%64,6), İyi Parti $140.421(29,5)$, SP 15.502 $(\% 3,26)$, DP $3.747(\% 0,79)$, BTP $2.821(\% 0,59)$, DSP $2.117(\% 0,45)$, Bağımsı $1.391(\% 0,29)$, VP 1.335 $(\% 0,28)$, TKP $950(\% 0,20)$ oy sayısı ve oranına ulaşılmaktadır. Kazanan oyların \%64,6'sını alarak Cumhur İttifakı adayı Murat ZORLUOĞLU'dur. Kadın adaylar \%0,59 ve \%0,29 oy oranı dilimiyle eril yerel siyasette kadın temsilinin yetersizliğini gözler önüne bir kez daha sermektedir.

\subsubsection{Belde Belediye Başkanlığı Düzeyinde Kadının Yokluk Sorunsalı}

Trabzon İline bağlı on sekiz beldede belediye başkanlığı makamına siyasal partilerce 98 kişi aday gösterilmektedir. Adayların cinsiyet bazında dağılımına bakıldığında 97'sinin (\%99) erkek, 1'inin (\%1) kadın olduğu görülmektedir. Tek kadın aday ise, Çaykara beldesinde İyi Parti teşkilatınca gösterilen Hanife Birinci'dir. Tablo 6'de beldeler özelinde partilerce belediye başkanlığına aday gösterilen kadın, erkek sayısına ve seçim sonuçlarına yer verilmektedir.

Tablo 6. 2019 Yerel Seçimlerinde Trabzon Büyükşehir Belediyesi Merkez ve Belde Belediye Başkanlığına Aday Olan ve Kazanan Kadın, Erkek Sayısı/Oranları

\begin{tabular}{|c|c|c|c|c|c|c|}
\hline \multirow{2}{*}{ Belde } & \multicolumn{5}{|c|}{ Belde Belediye Başkanı Adayları 31.03.2019 } & \multirow{2}{*}{$\begin{array}{c}\text { Kazanan Kadın } \\
\text { Aday Sayısı }\end{array}$} \\
\cline { 2 - 6 } Akçaabat & Kadın & Yüzdesi & Erkek & Yüzdesi & Toplam & 0 \\
\hline Arakıı & 0 & $\% 0$ & 5 & $\% 100$ & 5 & 0 \\
\hline Arsin & 0 & $\% 0$ & 7 & $\% 100$ & 7 & 0 \\
\hline Beşikdüzü & 0 & $\% 0$ & 5 & $\% 100$ & 5 & 0 \\
\hline Çarşıbaşı & 0 & $\% 0$ & 6 & $\% 100$ & 6 & 0 \\
\hline Çaykara & 1 & $\% 12,5$ & 7 & $\% 87,5$ & 8 & 0 \\
\hline Dernekpazarı & 0 & $\% 0$ & 6 & $\% 100$ & 6 & 0 \\
\hline Düzköy & 0 & $\% 0$ & 4 & $\% 100$ & 4 & 0 \\
\hline Hayrat & 0 & $\% 0$ & 3 & $\% 100$ & 3 & 0 \\
\hline Köprübaşı & 0 & $\% 0$ & 5 & $\% 100$ & 5 & 0 \\
\hline Maçka & 0 & $\% 0$ & 5 & $\% 100$ & 5 & 0 \\
\hline Of & 0 & $\% 0$ & 6 & $\% 100$ & 6 & 0 \\
\hline Ortahisar & 0 & $\% 0$ & 7 & $\% 100$ & 7 & 0 \\
\hline Sürmene & 0 & $\% 0$ & 5 & $\% 100$ & 5 & 0 \\
\hline Şalpazarı & 0 & $\% 0$ & 7 & $\% 100$ & 7 & 0 \\
\hline Tonya & 0 & $\% 0$ & 4 & $\% 100$ & 4 & 0 \\
\hline Vakfıkebir & 0 & $\% 0$ & 4 & $\% 100$ & 4 & 0 \\
\hline Yomra & 0 & $\% 0$ & 5 & $\% 100$ & 5 & 0 \\
\hline Toplam & $\mathbf{1}$ & $\% 1$ & $\mathbf{9 7}$ & $\% 99$ & $\mathbf{9 8}$ & $\mathbf{0}$ \\
\hline
\end{tabular}

Kaynak: www.ysk.gov.tr adresinin “31.03.2019 Mahalli İdareler Genel Seçimleri” 'kısmından derlenip, tablolaştırıldı. 
Seçimde "aday olma" düzeyinde toplam temsil sayı ve oranları; 1'i (\%1) kadın, 97'si (\%99) erkek olmak üzere 98'dir. Seçim sonucunda Akçaabat Ak Parti Osman Nuri Ekim 43.757 (\%60), Araklı Ak Parti Recep Çebi 15.089 (\%51,8), Arsin Ak Parti Muhammet Sait Gürsoy 12.974 (\%56,1), Beşikdüzü CHP Ramis Uzun 8.907 (\%60,5), Çarşıbaşı MHP Mümin Nuhoğlu 5.868 (\%53,3), Dernekpazarı Ak Parti Mehmet Aşık 2.156 (\%72,1), Düzköy Ak Parti Yılmaz Ankara 5.706 (\%58,5), Hayrat bağımsız aday Mehmet Nuhoğlu 3.868 (\%52,4), Köprübaşı Ak Parti Ali Aydın 2.062 (\%49,3), Maçka Ak Parti Koray Koçkan $11.002(\% 59,2)$, Of Ak Parti Salim Salih Sarıalioğlu 15.433 (\%57,6), Ortahisar Ak Parti Ahmet Metin Genç 98.977 (59,3), Sürmene Ak Parti Rahmi Üstün $8.911(54,5)$, Şalpazarı MHP Refik Kurukız $5.618(\% 60,8)$, Tonya Ak Parti Osman Beşel 5.937 (\%61), Vakfikebir Ak Parti Muhammet Balta $11.184(64,3)$ oy oranları ve yüzdeleriyle belediye başkanlığına seçilmektedir.

Tek kadın belde belediye başkanı gösteren Çaykara'da, Ak Parti Hanefi Tok oyların $7.257(\% 65,5)$ 'ini alırken, İyi Parti Hanife Birinci 893 (\%8,07)'si ile dördüncü sırada yer almaktadır. Yukarıdaki sonuçlarla yerel seçimlerde kadın temsilindeki yokluk sorunsalı tarihsel tekerrür misali yaşanmaya devam etmektedir.

\subsection{3 İl Genel ve Belde Meclis Üyeliği Düzeyinde Kadın Temsili İronisi}

İlk olarak büyükşehir belediye meclislerinin nasıl oluşturulduğunun izah edilmesi gerekir. 2972 sayılı "Mahalli İdareler ile Mahalle Muhtarlıkları ve İhtiyar Heyetleri Seçimi Hakkında Kanun”a göre, büyükşehir belediye meclisi üyelerinin seçimi doğrudan gerçekleşmemektedir. Bunun yerine, belde belediyelerine seçimle gelen üyelerin bir bölümün büyükşehir belediye meclisine gönderilmektedir. Belde belediyelerinin bu yolla, büyükşehir belediyesinin karar alma organına katılması sağlanmaktadır. Belde belediye meclislerinde, aday listeleri oluşturulurken asil, yedek adayların yanında kontenjan adaylarına ayrıca yer verilmektedir. Başkan seçildiğinde kontenjan adaylar doğrudan seçilirken, asil adaylar partinin oy oranına göre D'Hondt sistemi kullanılarak meclis üyeleri belirlenmektedir. Tablo 7'de kanun kapsamında nüfus aralığına göre beldelerde olması gereken belediye meclis ve kontenjan üye sayıları gösterilmektedir.

Tablo 7. 2972 sayılı “Mahalli İdareler ile Mahalle Muhtarlıkları ve İhtiyar Heyetleri Seçimi Hakkında Kanun'” Kapsamında Nüfus Aralığına Göre Toplam Meclis ve Kontenjan Üye Sayıları

\begin{tabular}{|c|c|c|c|c|c|c|c|c|}
\hline & \multicolumn{8}{|c|}{ Nüfus Aralığı } \\
\hline & 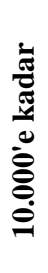 & 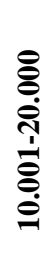 & 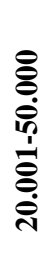 & 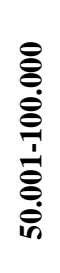 & 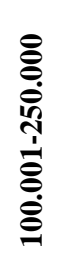 & 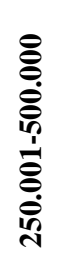 & 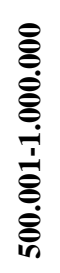 & 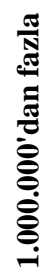 \\
\hline Toplam Meclis Üyesi Sayısı & 9 & 11 & 15 & 25 & 31 & 37 & 45 & 55 \\
\hline Kontenjan Meclis üyesi Sayısı & 1 & 1 & 2 & 3 & 3 & 4 & 5 & 6 \\
\hline
\end{tabular}

Büyükşehir sınırları kapsamındaki belde belediyelerindeki kesin seçim sonuçlarına göre, belediye meclis üyeleri her beldenin belediye başkanı ve meclis üye sayısının beşte biriyle oluşturulmaktadır. Kontenjan adayı meclis üyeliği bağlamında seçilen ilk kişidir. Oy oranının farkı dikkate alınarak ikinci, üçüncü ve devamındaki üyeler kazanan belediye başkan adayının partisinden seçilerek, büyükşehir belediye meclisine girmektedir. Bu bilgiler bağlamında önce Tablo 8'de Trabzon beldelerinin nüfuslarına dair bilgiler sunulmaktadır. Akabinde Tablo 9'da Trabzon büyükşehir belediyesine bağlı başta merkez olmak üzere diğer beldelerinde meclis üyeliğine aday, kazanan erkek, kadın sayı ve oranlarına yer verilmektedir. 
Tablo 8. Trabzon İlinin Beldelerindeki Nüfusun Erkek, Kadın Sayısı ve Oranları

\begin{tabular}{|c|c|c|c|c|c|}
\hline Belde & Toplan Nüfus & Erkek Nüfusu & Erkek Oranı & Kadın Nüfusu & Kadın Oranı \\
\hline Ortahisar & 328.457 & 161.085 & $\% 49,04$ & 167.372 & $\% 50,96$ \\
\hline Akçaabat & 125.848 & 62.382 & $\% 49,57$ & 63.466 & $\% 50,43$ \\
\hline Araklı & 48.660 & 24.426 & $\% 50,20$ & 24.234 & $\% 49,80$ \\
\hline Of & 43.082 & 21.488 & $\% 49,88$ & 21.594 & $\% 50,12$ \\
\hline Yomra & 41.516 & 20.719 & $\% 49,91$ & 20.797 & $\% 50,09$ \\
\hline Arsin & 32.063 & 16.187 & $\% 50,48$ & 15.876 & $\% 49,52$ \\
\hline Vakfıkebir & 27.525 & 13.503 & $\% 49,06$ & 14.022 & $\% 50,94$ \\
\hline Sürmene & 26.824 & 13.547 & $\% 50,50$ & 13.277 & $\% 49,50$ \\
\hline Maçka & 25.363 & 12.660 & $\% 49,92$ & 12.703 & $\% 50,08$ \\
\hline Beşikdüzü & 23.328 & 11.719 & $\% 50,24$ & 11.609 & $\% 49,76$ \\
\hline Çarşıbaş̧ı & 15.562 & 7.953 & $\% 51,11$ & 7.609 & $\% 48,89$ \\
\hline Çaykara & 14.379 & 7.246 & $\% 50,39$ & 7.133 & $\% 49,61$ \\
\hline Tonya & 14.116 & 6.783 & $\% 48,05$ & 7.333 & $\% 51,95$ \\
\hline Düzköy & 13.909 & 6.828 & $\% 49,09$ & 7.081 & $\% 50,91$ \\
\hline Şalpazarı & 11.015 & 5.439 & $\% 49,38$ & 5.576 & $\% 50,62$ \\
\hline Hayrat & 8.490 & 4.298 & $\% 50,62$ & 4.192 & $\% 49,38$ \\
\hline Köprübaşı & 4.851 & 2.487 & $\% 51,27$ & 2.364 & $\% 48,73$ \\
\hline Dernekpazarı & 3.986 & 1.973 & $\% 49,50$ & 2.013 & $\% 50,50$ \\
\hline
\end{tabular}

Kaynak: 2019 verileri bağlamında www.tuik.gov.tr'den derlenerek, tablolaştırıldı.

Yukarıdaki tabloda nüfus yoğunluğunun en fazla oluğu beldeden en az olanına doğru bir sıralama yöntemi izlenmektedir. Buradaki verilerden erkek ve kadın nüfusu arasında beldeler bağlamında çok fazla bir farkın olmadığı, onunda kadın nüfusunun daha fazla olduğu görülmektedir. Tablo 9'da verilen bilgiler doğrultusunda öncelikle, partilerce kadın adayların yedek, asıl, kontenjan türünden ve kaçıncı sıradan gösterildikleri, akabinde eğitim, meslek durumları incelenmektedir.

Akçaabat'ta BTP asıl listeden 17. , 21. , 22. , 23. , 24. , 25. , 27. sıradan ortaokul/lise mezunu ev hanımı yedi aday göstermektedir. Ak Parti asıl 6. ve 17. sıradan üniversite mezunu emekli öğretmen/mimar iki; yedek listeden 1. , 4. , 11. , 16. , 20. , 22. , 29. , 31. sıradan biri ilkokul diğerleri ortaokul/lise mezunu işçi, esnaf, güvenlik görevlisi, serbest çalışan; 6. , 8. , 15. , 27. sıradan üniversite mezunu biri ev hanımı diğerleri esnaf ve terzi olan kadın adaya yer vermektedir. Iyi Parti'den asıl listeden 9. sıradan ortaokul/lise mezunu ev hanımı; 19. ve 21. sıradan üniversite/yüksekokulu mezunu turizmci ve serbest çalışan yer almaktadır. Yedek listedeki iki adayı kadın olup, ortaokul/lise mezunu muhasebecidir. $S P, V T, T K P, B B P$ 'nin ise hiçbir kadın adayı yoktur.

Araklı'da, BTP'nin tek yedek adayı ilkokul mezunu kadındır. BBP asıl 6. sıradan ortaokul/lise mezunu hemşire, yedek 15. sıradan ev hanımı ilkokul/ortaokul mezunu kadın aday göstermektedir. Ak Parti'nin asıl 10. sıradan emekli/ilkokul, yedekten 1. , 12. , 13. sıradan ev hanımı ilkokul, işçi üniversite/yüksekokul, çiftçi ilkokul/ortaokul mezunu kadın adayı vardır. Lyi Parti'den asıl listeden 5. sıradan gösterilen ortaokul/lise mezunu ev hanımıdır. $D P, D S P, V P, T K P, S P$ 'nin kadın adayı yoktur. Arsin'de ise, $S P$ 'nin asıl listeden 10. siradan kadın adayı ilkokul mezunu ev hanımıdır. BTP'nin tek asıl adayı ilkokul/ortaokul mezunu kadındır. $V P$ ise, asıl listesinden 10. sıradan çiftçi ortaokul/lise mezunu kadın adaya yer açmaktadır. Ak Parti asıl listeden 2. ve 4. sıradan avukat/mimar iki, yedekten ise 1. , 5. , 9. , 14. siradan ortaokul/lise/ev hanımı, 12. ve 13. sıradan ilkokul/ev hanımı, psikolog üniversite/yüksekokul mezunu altı kadına yer verir. BBP ve İyi Parti'nin kadın adayı yoktur. 
Tablo 9. 31.03.2019 Yerel Seçimlerinde Trabzon Büyükşehir Belediyesi Belde Belediye Meclis Üyeliğine Aday Olan ve Kazanan Kadın, Erkek Sayısı/Oranları

\begin{tabular}{|c|c|c|c|c|c|c|c|c|}
\hline \multirow{2}{*}{ Beldeler } & \multicolumn{5}{|c|}{ Belde Belediye Meclis Üyesi Adayları 31.03.2019 } & \multirow{2}{*}{$\begin{array}{c}\text { Kazanan } \\
\text { Kadın Sayısı }\end{array}$} & \multirow{2}{*}{$\begin{array}{c}\text { Kazanan } \\
\text { Erkek Sayısı }\end{array}$} & \multirow{2}{*}{ Toplam } \\
\hline & Kadın & Yüzdesi & Erkek & Yüzdesi & Toplam & & & \\
\hline Akçaabat & 26 & $\% 15.75$ & 134 & $\% 84.25$ & 160 & 2 & 29 & 31 \\
\hline Araklı & 8 & $\% 7.21$ & 103 & $\% 92.79$ & 111 & 1 & 14 & 15 \\
\hline Arsin & 11 & $\% 13.92$ & 69 & $\% 86.08$ & 80 & 2 & 13 & 15 \\
\hline Beşikdüzü & 10 & $\% 13.51$ & 64 & $\% 86.49$ & 74 & 2 & 15 & 17 \\
\hline Çarşıbaşı & 5 & $\% 8.33$ & 55 & $\% 91.67$ & 60 & 1 & 10 & 11 \\
\hline Çaykara & 8 & $\% 11.59$ & 61 & $\% 88.41$ & 69 & 1 & 10 & 11 \\
\hline Dernekpazarı & 2 & $\% 5.71$ & 33 & $\% 94.29$ & 35 & 1 & 8 & 9 \\
\hline Düzköy & 3 & $\% 6.67$ & 42 & $\% 93.33$ & 45 & - & 11 & 11 \\
\hline Hayrat & 0 & $\% 0$ & 41 & $\% 100$ & 41 & - & 11 & 11 \\
\hline Köprübaşı & 6 & $\% 12$ & 44 & $\% 88$ & 50 & - & 9 & 9 \\
\hline Maçka & 7 & $\% 011.11$ & 56 & $\% 88.89$ & 63 & - & 15 & 15 \\
\hline Of & 9 & $\% 9.38$ & 87 & $\% 90.62$ & 96 & 1 & 14 & 15 \\
\hline Ortahisar & 31 & $\% 14.98$ & 176 & $\% 84.02$ & 207 & 4 & 43 & 47 \\
\hline Sürmene & 9 & $\% 9.57$ & 85 & $\% 90.43$ & 94 & - & 15 & 15 \\
\hline Şalpazarı & 8 & $\% 17.02$ & 39 & $\% 82.98$ & 47 & - & 11 & 11 \\
\hline Tonya & 4 & $\% 7.84$ & 47 & $\% 92.16$ & 51 & 1 & 10 & 11 \\
\hline Vakfıkebir & 11 & $\% 15.28$ & 61 & $\% 84.72$ & 72 & 1 & 14 & 15 \\
\hline Yomra & 9 & $\% 0$ & 61 & $\% 100$ & 70 & 3 & 12 & 15 \\
\hline Toplam & 167 & $\% 11.72$ & 1.258 & $\% 88.28$ & 1.425 & 20 & 264 & 284 \\
\hline
\end{tabular}

Kaynak: Yazar tarafindan www.ysk.gov.tr ve www.tuik.gov.tr adreslerinde bulunan verilerden derlenip, tablolaştırıld1.

Beşikdüzü'nde, TKP'nin asıl listeden tek adayı, üniversite mezunu hemşire kadındır. CHP asıl listede 2. ve 7. sıradan inşaat mühendisi/emekli öğretmen üniversite mezunu kadın adaya yer verilmektedir. Ak Parti ise, asıl listesinden 3. ve 11. sırayı üniversite/yüksekokul mezunu serbest çalışan/gazeteci, yedekten 3. sıradan üniversite/yüksekokul mezunu serbest mesleği olan kadına ayrılmaktadır. $D P$, asıl listeden 7. ve 9. sıradan ortaokul/lise mezunu pazarlamac1/serbest çalışan; 8 . ve 11. sıradan üniversite/yüksekokul mezunu turizm/muhasebe, 13. sıradan ilkokul mezunu serbest çalışan kadın aday gösterilmektedir. $S P, B T P, V P$, $B B P$ 'nin kadın adayı yoktur.

Çarşıbaşıı'nda, MHP asıl listeden 8. sıradan ev hanım ortaokul/lise, yedekten 1. ve 3. sırandan ortaokul/lise mezunu ev hanımı/turizmciye yer verilmektedir. $D P$ asıl listeden 1. sırayı serbest meslek çalışanı üniversite/yüksekokul mezunu kadın adaya açmaktadır. İyi Parti asıl listede 2. Sıradaki adayı işletmeci üniversite/yüksekokul mezunu kadındır. $S P, B T P, T K P, B B P$ 'nin kadın adayı yoktur.

Çaykara'da, $S P$ asıl listeden 6. sıradan ortaokul/lise, serbest çalışan; 10. sıradan ilkokul/ev hanımı kadına yer verir. $B T P$ asıl listesinde tek aday ilkokul ev hanımı, $T K P$ ise üniversite/yüksekokul, fizik tedavi uzmanı; $B B P$ asıl 6. sıradan ortaokul/lise mezunu işçi kadındır. Ak Parti asıl 10. Sıradan adayı ilkokul ve yedekten 7. sıradan üniversite/yüksekokul mezunu kadın adaydır. L̇yi Parti'nin asıl 8. sıradan adayı, serbest çalışan ilkokul mezunu kadındır. VP, CHP listelerinde kadın adaya yer vermemektedir.

Dernekpazarl'nda, sadece $A k$ Parti asıl listeden esnaf ortaokul/lise mezunu ve yedekten 8 . siradan serbest çalışan kadındır. Burada $S P, B T P, T K P, B B P$, İyi Parti'nin göstermiş olduğu kadın adaya rastlanılmamaktadır.

Düzköy'de BTP ve TKP'nin asıl listeden tek adayı, ilkokul/serbest çalışan ve emekli üniversite/yüksekokul mezunu kadındır. $C H P$ asıl listeden 10. sıradan ortaokul/lise/ev hanımı kadına yer vermektedir. SP, Ak Parti'nin 
kadın adayı yoktur. Hayrat beldesinde hiç bir partinin kadın adayı yoktur. Köprübaşı'nda ise, BTP asıl listeden tek adayı ortaokul/lise mezunu ev hanımıdır. Ak Parti asıl listeden 8. sıradan ortaokul/lise serbest çalışan, yedekten 2. ve 5. sıradan üniversite/yüksekokul/öğretmen ve serbest çalışan 7. siradan ilkokul mezunu serbest çalışana yer vermektedir. $S P, T K P, B B P$ kadın aday göstermemektedir.

$M a c ̧ k a$ 'da, CHP asıl listeden 3. sıradan ortaokul/lise/mesleği belirtilmemiş, yedekten 6. sıradan ortaokul/lise, 7. sıradan üniversite/yüksekokul, 2. sıradan kontenjan adayı ortaokul/lise mezunu kadın adaya ayırmaktadır. $A k$ Parti'nin ise, as1l listeden ortaokul/lise, yedekten 4. sıradan ortaokul/lise ve 11. sıradan üniversite/yüksekokul mezunu meslek belirtilmemiş kadın adayı vardır. $S P, B T P, T K P$, VP ve BBP'nin kadın adayı yoktur.

$O f^{\prime}$ ta, $C H P$ asıl listeden kadın adayı 6. , 8. , 12. sıradan ortaokul/lise mezunu ev hanımı ve ögrencidir. Ak Parti asıl listeden 10. sırada ortaokul/lise işçi, yedekten 7. ve 13. sırada ortaokul/lise mezunu ev hanımı yer almaktadır. DP 3. yedekten üniversite/yüksekokul ev hanımına; Iyi Parti asıl listesinden 4. ve 5. siradan emekli ortaokul/lise, işçi üniversite/yüksekokul mezunu kadına yer açmaktadır. $S P, B T P, T K P, B B P$ 'nin listelerinde kadın aday yer almamaktadır.

Ortahisar merkezde ise, $S P$ 9. ve 17. sıradan ilkokul ve üniversite/yüksekokul yönetici; $T K P$ ise tek asıl adayını üniversite/yüksekokul mezunu büro çalışanına kadına rastlanılmaktadır. BTP 2. , 11. , 17. sıradan ortaokul/lise/ev hanımı, 1. , 3. , 4. , 19. sıradan üniversite/yüksekokul mezunu diş hekimi, inşaat mühendisi, iç mimar, serbest çalışan kadına yer verilmektedir. CHP ise asıl listeden 5. , 9. , 18. sırana üniversite/yüksekokul mezunu mühendis ve emekli; yedekten ortaokul/lise öğrencisine ayırmaktadır. DP 25 ve 27. sıradan ortaokul/lise mezunu serbest çalışan ve öğrenci kadın adayı vardır. Ak Parti'nin ise, 5. , 12. , 26. sıradan üniversite/yüksekokul inşaat mühendisi, mimar, sigortacı ve 31. sıradan emekli ortaokul/lise mezunu adayları kadındır. Yedek listede 2. , 21. , 36. sıradan ev hanımı ve mali müşavir üniversite/yüksekokul; 9. , 23. , 25. , 29. , 31. sıradan işletmeci, danışman, eğitmen, müşteri temsilcisi, ev hanımı ortaokul/lise mezunu kadın adaya yer verilmektedir. $B B P, H D P, D S P$ 'nin kadın adayı yoktur.

Sürmene'de $B B P$ asıl listesinden 13. , en son ve yedekten 10. siradan ilkokul/ortaokul mezunu ev hanımına yer vermektedir. TKP, tek aday olarak gösterdiği kimyager, üniversite/yüksekokul mezunu kadındır. CHP asıl listeden 11. sıradan adayı ortaokul/lise mezunu ev hanımıdır. Ak Parti, asıl 13. sıradan ortaokul/lise/rehber personeli; yedekten 12. ve 14. sıradan üniversite/yüksekokul/muhasebe müdürü ve öğrenci, 4. sıradan ilkokul/aşçı, 13. sırada ortaokul/lise mezunu eczacı teknisyen yer almaktadır. SP, BTP kadın adayı yoktur.

Şalpazarı'nda, BTP'nin tek asıl adayı ortaokul/lise yazılımc1; TKP de benzer şekilde üniversite/yüksekokul mezunu benzer meslekten kadın adaydır. Iyi Parti yedekten ilk sıradan ortaokul/lise ev hanımı; $M H P$ ise sadece yedekten 1. , 5. , 6. , 11. sıradan ilkokul/ortaokul lise ev hanımı, esnaf ve işçiye, 4. sıradan üniversite/yüksekokul mezunu serbest çalışan kadına yer vermektedir. $S P$ ve $D P$ 'nin kadın adayı yoktur.

Tonya' da CHP ası1 8. sıradan ortaokul/lise mezunu meslek belirtilmemiş adayı vardır. Ak Parti, asıldan 5. sırada üniversite/yüksekokul, yedekten 4. ve 9. sırada ortaokul/lise/üniversite mezunu meslek belirtilmemiş adayı yer almaktadır. $S P, T K P, V P, B B P$ 'nin listelerinde kadın adaya rastlanılmamaktadır.

Vakfikebir'de BTP iki asıl adayı ev hanımı ortaokul/lise mezunudur. CHP 6. ve 7. sıradan üniversite/yüksekokul ekonomist ve serbest çalışan, 8. sıradan ilkokul mezunu serbest çalışandır. Ak Parti ise asıl 5. ve 11. sıradan ortaokul/lise/üniversite; yedekten 1. sıradan üniversite/yüksekokul inşaat mühendisi, 9. , 11. , 15. sıradan ortaokul/lise mezunu işçi ve ev hanımı kadın adaydır. $S P, B T P, V P, B B P, D P$ kadın adayı yoktur.

Yomra'da, BTP asıl ilk sıradan ortaokul/lise serbest çalışan; Iyi Parti listesinde benzer sıradan ortaokul/lise mezunu iş kadınına yer vermektedir. Ak Parti, asıl 2. sıradan inşaat mühendisi yedekten 5. , 14. ve 15. sıradan ortaokul/lise/ilkokul mezunu, ev hanımına; 2. ve 6. siradan üniversite/yüksekokul mezunu peyzaj mimar ve muhasebeci adayın yanı sıra kontenjan adaylığında ilk sırayı müteahhit ortaokul/lise mezunu kadın aday yer almaktadır. $\mathrm{Bu}$ beldede bağımsız ve $S P, B T P, \quad V P, B B P, \quad T K P$ tarafından gösterilen kadın adaya rastlanılmamaktadır.

Seçim sonucu ise yukarıda detaylı olarak ifade ettiğimiz mevzuat çerçevesinde gerçekleşmektedir. Belde ve büyükşsehir belediye meclis üyesi dağılımı yapılmaktadır. Tablo $10^{\prime}$ da büyükşehir belediye meclis üyesi dağılımı erkek, kadın sayı ve oranlarıyla gösterilmektedir. 
Tablo 10. 31.03.2019 Yerel Seçimlerinde Trabzon Büyükşehir Belediyesi Beldelerinde İl Genel Meclis Üyeliği Sayıları: Kadın ve Erkek Dağılımı

\begin{tabular}{|c|c|c|c|c|c|}
\hline \multirow{2}{*}{ Beldeler } & \multicolumn{5}{|c|}{ Büyükşehir Belediyesi Meclis Üyeleri 31 Mart 2019} \\
\hline & Kadın & Yüzde Oranı & Erkek & Yüzde Oranı & Toplam \\
\hline Akçaabat & $\mathbf{0}$ & $\% 0$ & 7 & $\% 100$ & 7 \\
\hline Araklı & $\mathbf{0}$ & $\% 0$ & 4 & $\% 100$ & 4 \\
\hline Arsin & 1 & $\% 25$ & 3 & $\% 75$ & 4 \\
\hline Beşikdüzü & $\mathbf{0}$ & $\% 0$ & 4 & $\% 100$ & 4 \\
\hline Çarşıbaşı & $\mathbf{0}$ & $\% 0$ & 3 & $\% 100$ & 3 \\
\hline Çaykara & $\mathbf{0}$ & $\% 0$ & 3 & $\% 100$ & 3 \\
\hline Dernekpazarı & $\mathbf{0}$ & $\% 0$ & 2 & $\% 100$ & 2 \\
\hline Düzköy & $\mathbf{0}$ & $\% 0$ & 3 & $\% 100$ & 3 \\
\hline Hayrat & 0 & $\% 0$ & 3 & $\% 100$ & 3 \\
\hline Köprübaşı & 0 & $\% 0$ & 2 & $\% 100$ & 2 \\
\hline Maçka & $\mathbf{0}$ & $\% 0$ & 4 & $\% 100$ & 4 \\
\hline Of & $\mathbf{0}$ & $\% 0$ & 4 & $\% 100$ & 4 \\
\hline Ortahisar & $\mathbf{0}$ & $\% 0$ & 8 & $\% 100$ & 8 \\
\hline Sürmene & $\mathbf{0}$ & $\% 0$ & 4 & $\% 100$ & 4 \\
\hline Şalpazarı & $\mathbf{0}$ & $\% 0$ & 3 & $\% 100$ & 3 \\
\hline Tonya & $\mathbf{0}$ & $\% 0$ & 3 & $\% 100$ & 3 \\
\hline Vakfikebir & $\mathbf{0}$ & $\% 0$ & 4 & $\% 100$ & 4 \\
\hline Yomra & 2 & $\% 50$ & 2 & $\% 50$ & 4 \\
\hline Toplam & 3 & $\% 4,35$ & 66 & $\% 95,65$ & 69 \\
\hline
\end{tabular}

Kaynak: Yazar tarafindan www.trabzon.bel.tr adresinin “Belediye Meclisi” kısmından derlenip, tablolaştırıldı.

Öncelikle Tablo 9'da görüldüğü üzere “seçilme" düzeyinde temsil sayısı, 264 erkek ve 20 kadın toplamda 284 'tür. Beldeler bağlamında kazananların dağılımı önem arz etmektedir. Akçaabat'ta Ak Partili 8. ve 24. ; Arakll'da 11.; Arsin'den 2. ve 5. ; Beşikdüzü'nden 7. asıl sıradan gösterilen adayların kazandığı görülmektedir. Beşikdüzü'nde ikinci kazanan CHP'li 11. asıl sıradaki kadın adaydır. Çarşıbaşı'nda İyi Parti'den 5. asıl sıradan gösterilen aday seçilmektedir. Çaykara'da Ak Partili 10. ; Dernekpazarı 5. ; Of'ta 10. asıl sıradaki kadın aday kazanmaktadır. Ortahisar'da Ak Parti'den 7. ve 17. ile CHP'den 15. ve 27. ası1 sıradaki aday seçilme imkânı bulmaktadir. Tonya'da Ak Parti'den 7. ; Vakfikebir'de 6. asıl sıradaki ile Yomra'da Ak Parti'den 3. asil ve ilk sıradaki kontenjan adayı, İyi Partili 2. asıl adayın belediye meclisine girmektedir. Maçka, Sürmene, Şalpazarı, Düzköy, Hayrat, Köprübaşı belde belediye meclislerine seçilen kadın adaya rastlanılmamaktadır.

Tablo 9'deki bilgiler doğrultusunda belediye meclisi üyeliğine "aday olma" düzeyinde temsilin 167 (\%11.72) kadın ve 1258 (\%88.28) erkek toplam 1463'tür. 'Seçilme”' düzeyinde temsile bakıldığında, 284 adaydan 20'si (\%7.05) kadın ve 260’1 (\%91.55) erkek olduğu görülmektedir. Tablo 10 incelendiğinde, belde belediye meclisine seçilen 20 kadın üyelerden sadece 3'ünün büyükşehir belediyesi meclis üyeliğine seçildiğine rastlanılmaktadır. Büyükşehir belediye meclisinde "seçilme" düzeyinde toplam temsil sayı ve oranları 69 üyeden 66’sı (\%95.65) erkek ve 3'ü (\%4.35) kadın şeklinde olmaktadır. Burada 2972 sayılı kanun gereği kadın adayların aday gösterilmesi sırası, özellikle kontenjan adaylı̆̆ı önem taşımaktadır. Aday kadınların çoğunun geri sıralarda yer aldığı görülmektedir. Oy potansiyeli yüksek partilerce ilk sıralardan aday gösterilen kadınların, partinin kazanması neticesinde kolaylıkla seçildiği alenen ortadadır.

Bütün bu bilgiler ışında tarihsel süreçte kadın adaylar için değişmeyen kaderin tekrarlandığı görülmektedir: Yerel siyasette yetersiz temsil, görünmezlik ve yokluk ironisi, vitrin görevi. 


\section{SONUÇ ve DEĞERLENDİRME}

Trabzon'un nüfusu 2019 y1lı verilerine göre, 400.723'ü (49.53) erkek, 408.251'i (50.47) kadın toplam 808.974'tür. Belde bazında ise on sekizinin onunda kadın nüfus oranı erkekten daha fazladır. Özetle, Türkiye'deki nüfus dağılımına paralel bir durumun Trabzon İlinde olduğu görülmektedir. Kadınlar toplam nüfus içinde erkeklerden sayısal olarak fazla olmalarına rağmen, kamusal alandaki varlıkları yokluk derecesindedir. Özellikle yerel siyasette kadın görünmez bir konumdadır. Bu durum çözümü bekleyen bir sorunsal olarak, geçmişten günümüze miras kaldığı ortadır.

Büyükşehir belediyesi olan Trabzon'da adayın kaçıncı sıradan gösterilişi, belde meclis, özellikle il genel meclis üyeliğine seçilmede etkili olduğu göz önüne alındığında, kadınların partilerce nasıl yerel siyasette "görünmez" kabul edilip "yokluk" sınırına itildiği, sadece "sembolik" değer verilerek kabul gördüğünün eril izlerinin tekrarlandığı görülmektedir. Aşağıda verilen bilgiler ışığında, söz konusu durum ispatlanmaya çalışılmaktadır.

Çalışmada oluşturulan tablolarda ortaya çıkan sonuçlar, Trabzon İlinde gerçekleşen 31 Mart 2019 Mahalli İdareler Genel Seçimlerinde, büyükşehir ve belde belediye başkanlığı düzeyinde “aday olma” düzeyinde kadın temsilinin sırasıyla \%22.2 ve \%1 seviyesindedir. Fakat "seçilme" düzeyinde temsile rastlanılmamaktadır. Bu durum yerel seçimlerde kabul gören yokluk sorunsalını kanıtlar niteliktedir. Belde belediye meclis üyeliğinde "aday olma" \%11.72'lik, "seçilme" düzeyinde \%7.05; il genel meclisi üyeliğinde "aday olma" \% 7.05, “seçilme” düzeyi özelinde \%4.35'lik seviyede olduğu tespit edilmektedir. Bu oranlar, gerek ulusal gerekse de uluslararası kadın platformlarında talep edilen \%30 ila 40 kadın kotasının çok uzağında kaldığı açıkça ortadadır.

Trabzon İli özelinde yaptığımız bu araştırmada yüksek oy oranına sahip partilerce aday gösterilen kadınların, listelerde sıralama bakımından orta ve sonlarda, çoğunlukla yedek listelerde yer aldığı tespit edilmektedir. Bu durum, kadın kotasını doldurmak isteyen partilerin başvurduğu bir taktiktir. Aday listeleri incelendiğinde düşük oy oranına sahip partilerin çoğunlukla kadın adaylara ilk sıradan ve fazlaca yer verildiğine rastlanılmaktadır. Söz konusu partilerde benzer amaçla, kadın adaylarını sayısal olarak fazla göstermeye çalıştıkları alenen ortadadir.

Mesleki düzeyde bakıldığında, ilkokul/ortaokul/lise mezunu ev hanımı ve çeşitli işlerde çalışan (terzi, muhasebeci, işçi vb.) kadın aday sayısı fazladır. Üniversite mezunu belli statü sahibi kadınların, partilerin oy oranının yüksek olduğu yerlerde ilk sıralardan kendine yer bulup, kolaylıkla seçildiği görülmektedir. Ekonomik bakımdan güçlü kadınların varlığı, siyasal alanda bu seviyede olmadan yer alınamayacağını bir kez daha ispat etmektedir. Bütün bu bilgiler ışında Trabzon İli özelinde Türkiye'deki yerel siyasette kadın temsilinin yeterli düzeye hala erişemediği tezi sınanarak, doğrulanmaktadır.

Siyasette görülen kadın katılım ve temsilindeki sınırlılık, toplumdaki cinsiyet eşitsizliğinin tezahürünün tek bir alandaki örneğini teşkil etmektedir. Söz konusu eşitsizliği hem siyasal hem de diğer alanlarda ortadan kaldırabilmek için toplumsal cinsiyet eşitliliğini merkeze koymuş, Gender Mainstreaming gibi, yaklaşımlara ihtiyaç vardır. Ayrıca kadın kotası olarak en az \%30'luk oran ve kadın kollarının partilerin yan kuruluşu olmaktan çıkarılıp, güçlendirilmesi siyasette kadının sayısal varlığını arttıracaktır. Fakat söz konusu biçimsel mekanizmaların yanı sıra niteliksel olarak kadın sorunlarını bilen buna çözüm üretebilecek yüksek kültür ve bilinç seviyesine sahip kadın adaylara ihtiyaç vardır. Bunun içinde STK'lara özellikle kadın dernek/kuruluşlarına büyük görev düşmektedir.

Son dönem seçim sonuçlarıyla kadının yerel siyasetteki katılım ve temsil sorunsalı bir kez daha yinelenmektedir. Siyasetin erkek işi olduğu algısının, kadınların temsil hakkını kanunen alması üzerinden uzun zaman geçmiş olsa da varlığını hala koruduğu açıkça ortadadır. Bunu değiştirecek olanın kadının kendisi olduğu unutulmamalıdır.

\section{KAYNAKÇA}

ARASLI, Oya (1972), Adaylık Kavramı ve Türkiye'de Milletvekilliği Adaylığı, Ankara Üniversitesi Hukuk Yayınları, Ankara.

ASLAN, Mehmet (2009), “Erillikten Dişiliğe Türkiye'de Kadın Belediye Başkanları”, Yayınlanmamış Yüksek Lisan Tezi, Akdeniz Üniversitesi Sosyal Bilimler Enstitüsü, Antalya. 
BALKIR, Z. Gönül (2012), “Toplumsal Cinsiyet ve Toplumsal Cinsiyet Ayrımcıll̆ğ’, Tübakkom: 1. Kadın Avukatlar Kurultayı Kitabı, Türkiye Barolar Birliği Yayınları, Ankara, ss.68-94.

BERKTAY, Fatmagül (2009), Tek Tanrılı Dinler Karşısında Kadın: Hıristiyanlıkta ve İslamiyet'te Kadının Statüsüne Karşılaştırmalı Bir Yaklaşım, Metis Yayınları, İstanbul.

BHASIN, Kamla (2003), Toplumsal Cinsiyet "Bize Yüklenen Roller" (Çev. Kader Ay), Kadav Yayınları, İstanbul.

BIRCH, Anthony Harold (1971), Representation, Pall Mall Press, London.

BULUT, Yakup ve TANIYICI, Şaban (2008), “Türkiye'de Belediye Meclis Üyelerinin Temsil Ediciliği: Erzincan Örneği”, Dumlupınar Üniversitesi Sosyal Bilimler Dergisi, S.21, ss.171-194.

CIVELEK, Sezen (2014), Toplumsal Cinsiyet Eşitliği: Temel Sorunlar ve Politika Önerileri, Tasav Beyin Fırtınası Toplantıları Kadın Hakları Çalışma Grubu Yayını, Ankara, www.turkakademisi.org (Erişim Tarihi: 30.10.2020).

ÇAM, Esat (1987), Siyaset Bilimine Giriş, Der Yayınları, İstanbul.

ÇİTÇİ, Oya (1989), Yerel Yönetimlerde Temsil (Belediye Örneği), TODAİE Yayını, Ankara.

ÇUKURÇAYIR, Mehmet Akif (2012), Siyasal Katılma ve Yerel Demokrasi, Çizgi Kitabevi, Konya, 4. Baskı.

DAHL, Robert (1963), Modern Political Analysis, Englewood Cliffs, Prentice-Hall Inc.

DAHL, Robert (1993), Demokrasi ve Eleştirileri (Çev. Levent Köker), Yetkin Basımevi, Ankara.

DÖKMEN, Zehra (2012), Toplumsal Cinsiyet, Remzi Kitabevi, İstanbul, 3. Bask1.

GIDDENS, Anthony (2000), Sosyoloji (Çev. Hüseyin Özel ve Cemal Güzel), Ayraç Yayınları, Ankara.

GÖKÇİMEN, Semra (2008), “Ülkemizde Kadınların Siyasal Hayata Katılım Mücadelesi”, Yasama Dergisi, S.10, ss.1-59.

HEYWOOD, Andrew (2007), Siyaset (Ed. Buğra Kalkan - Çev. Bekir Berat Özipek, Bican Şahin, Mete Yıldız, Zeynep Kopuzlu, Bahattin Seçilmişoğlu, AtillaYayla), Adres Yayınları, Ankara, 19. Baskı.

HUNTiNGTON, Samuel P. ve NELSON, Joan M. (1976), No Easy Choice Political Participation in Developing Countries, Harvard University Press, Mass - Cambridge.

KA-DER (2004), Kadın Sorunlarına Çözüm Arayışı Kurultayı, Kader Yayınları, İstanbul, https://kutuphane.tbmm.gov.tr (Erişim Tarihi: 30.10.2020).

KALAYCIOĞLU, Ersin (1983), Karşılaştırmalı Siyasal Katılma: Siyasal Eylemin Kökenleri Üzerine Bir İnceleme, İstanbul Üniversitesi Siyasal Bilimler Fakültesi Yayınları, İstanbul.

KILIÇ, Zeynep (2000), Eşitlik İçin Kota Politikaları, Ankara Üniversitesi Kadın Sorunları Araştırma ve Uygulama Merkezi Yayını, Ankara.

KIŞLALI, Ahmet Taner (1987), Siyaset Bilimi, Ankara Üniversitesi Basın Yayın Yüksekokulu Yayınları, Ankara.

KITE, Marry E. (1996), “Age, Gender and Occupotional Label: A Test of Social Role Theory', Psychology of Women Quarterly, S.20, ss.361-374.

KURTOĞLU, Ayça (2004), Hemşehrilik ve Şehirde Siyaset: Keçiören Örneği, İletişim Yayınları, İstanbul.

MILBRATH, W. Lester ve GOEL, Madan Lal (1977), Political Participation, Rand McNally Press, Chicago.

OGLESBY, Carole ve HILL, Karen (1993), Genderand Sport, Handbook of Research on Sport Psychology, Macmillian Publishing Company, New York.

ÖRS, Birsen (1997), “Siyasal Temsil ve Demokrasi”, İktisat Dergisi, S.374, ss.24-34.

ÖZTEKİN, Ali (2007), Siyaset Bilimine Giriş, Siyasal Yayınları, Ankara.

PINARCIOĞLU, Nihal Şirin (2017), "Eril Siyasette Kadın Temsili (Mi?)”, Batman Üniversitesi Yaşam Bilimleri Dergisi, S.1(7), ss.12-24. 
PİTKİN, Hanna Fenichel (1995), “Temsil”, Blackwell’in Siyasal Düşünce Ansiklopedisi II (Çev. Bülent Peker, Nevzat Kıraç), Ümit Yayıncılık, Ankara.

SANCAR, Serpil (2018), Siyasal Kararlara Katılımda Toplumsal Cinsiyet Eşitliği Haritalama ve İzleme Çalışması, Ceid Yayınları, Ankara.

SANCAR ÜŞÜR, Sepil (2000), "Siyasal Süreçlere Katılımda Kadın-Erkek Eşitliği, Kadın Erkek Eşitliğine Doğru Yürüyüş”, Eğitim, Çalışma, Yaşamı ve Siyaset, TÜSİAD Yayınları, İstanbul, ss.197-258.

SARTORI, Giovanni (1996), Demokrasi Teorisine Geri Dönüş (Çev. Tunçer Karamustafaoğlu ve Mehmet Turhan), Yetkin Yayınları, Ankara.

SCOTT, Joan W. (2007), Toplumsal Cinsiyet: Faydalı Bir Tarihsel Analiz Kategorisi (Çev. Aykut Tunç Kılıç ), Ayrıntı Yayınları, İstanbul.

ŞAKACI, Bige Kağan (2009), "Yerel Yönetim Seçim Sistemi ve Öneriler Yöntemi”, Yerel Yönetimlerin Güncel Sorunları: Küresel, Bölgesel ve Yerel Perspektifler (Ed. Kemal Görmez, Mustafa Ökmen), Beta Yayınları, İstanbul.

SAVRAN, Gülnur (2005), "80'li Yilların Kampanyaları ve Özel Alanın Politikası (Sorunlar ve Sorular)" Özgürlüğü Ararken: Kadın Hareketinde Mücadele Deneyimleri (Ed. Berivan Kum, Fatma Gülçiçek, Pınar Selek), Amargi Yayınları, İstanbul, ss.81-101.

TEKELİ, Şirin (1983), Kadınlar ve Siyasal Toplumsal Hayat, Birikim Yayınları, İstanbul.

TOSUN, Tanju ve TEPECIKLİOĞLU, Ali Onur (2014), "Siyasal Partiler, Siyasal Katıllm ve Propaganda", Siyaset Bilimi (Ed. Halis Çetin), Orion Kitabevi, Ankara, 4. Bask1, ss.471-505.

TRABZON BELEDIYE BAŞKANLIĞI (2020), Trabzon Belediye Başkanlığı Kurumsal Web Sayfası, www.trabzon.bel.tr (Erişim Tarihi: 27.11.2020).

TUSKAN, Aydeniz Alisbah (2012), "Toplumsal Cinsiyet Toplumda Kadına Biçilen Roller ve Çözümleri”, TBB Dergisi, http://tbbdergisi.barobirlik.org.tr/m2012-99-1179 (Erişim Tarihi: 30.10.2020).

TUIK - TÜRKIYE İSTATISTIKK KURUMU (2019), 2019 Türkiye Nüfusu İstatistikleri, TUİK Yayını, Ankara, www.tuik.gov.tr, (Erişim Tarihi: 04.11.2020).

TUIK - TÜRKIYE İSTATISTIK KURUMU (2019), Mahalli İdareler Genel Seçim Sonuçları, TUIKK Yayını, Ankara, www.tuik.gov.tr, (Erişim Tarihi: 02.01.2021).

TÜRELİ, Nesrin ve ÇAĞLAR, Nedret (2010), "Yerel Yönetimde Kadın Temsili - Isparta İli Örneği", Süleyman Demirel Üniversitesi Vizyoner Dergisi, S.1(2), ss.16-40.

TÜRK DİL KURUMU (2005), Türkçe Sözlük, Türk Dil Kurumu Yayını, Ankara, 10. Bask1.

ULUOCAK, Şeref, GÖKULU, Gökhan, BILLIR, Olgun, ETIZZR KARACIK, Nigar ve ÖZBAY, Dilek (2014), Toplumsal Cinsiyet Eşitsizliği ve Kadına Yönelik Şiddet, Paradigma Akademi Yayınları, Ankara.

ÜSTE, Bahar (2017), "Yerel Seçimlerin Cinsiyeti: Seçimler ve Kadın Temsili", İşletme Fakültesi Dergisi, S.1(18), ss.101-131.

YILDIRIM, Ali ve ŞİMŞEK, Hasan (2011), Sosyal Bilimlerde Nitel Araştırma Yöntemleri, Seçkin Yayıncılık, Ankara, 11. Bask1.

YSK - YÜKSEK SEÇIM KURULU (2009), "18 Nisan 1999 ve 28 Mart 2004 Mahalli İdareler Genel Seçim Sonuçları", Yüksek Seçim Kurulu Kurumsal Web Sayfası, www.ysk.gov.tr (Erişim Tarihi: 04.11.2020).

YSK - YÜKSEK SEÇIM KURULU (2020), “31 Mart 2019 Mahalli İdareler Genel Seçimleri Sonuçları", Yüksek Seçim Kurulu Kurumsal Web Sayfası, www.ysk.gov.tr, (Erişim Tarihi: 04.11.2020).

2972 sayılı Mahalli İdareler İle Mahalle Muhtarlıkları ve İhtiyar Heyetleri Seçimi Hakkında Kanun (18.01.1984 tarih ve 18285 say1l Resmi Gazete). 